\title{
Neglected but Potent Dry Forest Players: Ecological Role and Ecosystem Service Provision of Biological Soil Crusts in the Human-Modified Caatinga
}

\author{
Michelle Szyja ${ }^{1 *}$, Artur Gonçalves de Souza Menezes ${ }^{2}$, Flávia D. A. Oliveira ${ }^{2}$, Inara Leal ${ }^{2}$, \\ Marcelo Tabarelli ${ }^{2}$, Burkhard Büdel ${ }^{1}$ and Rainer Wirth ${ }^{1}$ \\ ${ }^{1}$ Plant Ecology \& Systematics, University of Kaiserslautern, Kaiserslautern, Germany, ${ }^{2}$ Departamento de Botânica, \\ Universidade Federal de Pernambuco, Recife, Brazil
}

OPEN ACCESS

Edited by:

Nicole Pietrasiak New Mexico State University,

United States

Reviewed by:

Scott Ferrenberg, New Mexico State University,

United States

Gianalberto Losapio,

ETH Zürich, Switzerland

${ }^{*}$ Correspondence:

Michelle Szyja

michelle.szyja@web.de

Specialty section:

This article was submitted to Biogeography and Macroecology,

a section of the journal

Frontiers in Ecology and Evolution

Received: 28 June 2019 Accepted: 25 November 2019

Published: 17 December 2019

Citation:

Szyja M, Menezes AGS, Oliveira FDA, Leal I, Tabarelli M, Büdel B and Wirth $R$ (2019) Neglected but Potent Dry Forest Players: Ecological Role and Ecosystem Service Provision of Biological Soil Crusts in the Human-Modified Caatinga. Front. Ecol. Evol. 7:482 doi: 10.3389/fevo.2019.00482
Biological soil crusts (biocrusts) have been recognized as key ecological players in arid and semiarid regions at both local and global scales. They are important biodiversity components, provide critical ecosystem services, and strongly influence soil-plant relationships, and successional trajectories via facilitative, competitive, and edaphic engineering effects. Despite these important ecological roles, very little is known about biocrusts in seasonally dry tropical forests. Here we present a first baseline study on biocrust cover and ecosystem service provision in a human-modified landscape of the Brazilian Caatinga, South America's largest tropical dry forest. More specifically, we explored (1) across a network of 340.1 ha permanent plots the impact of disturbance, soil, precipitation, and vegetation-related parameters on biocrust cover in different stages of forest regeneration, and (2) the effect of disturbance on species composition, growth and soil organic carbon sequestration comparing early and late successional communities in two case study sites at opposite ends of the disturbance gradient. Our findings revealed that biocrusts are a conspicuous component of the Caatinga ecosystem with at least 50 different taxa of cyanobacteria, algae, lichens and bryophytes (cyanobacteria and bryophytes dominating) covering nearly $10 \%$ of the total land surface and doubling soil organic carbon content relative to bare topsoil. High litter cover, high disturbance by goats, and low soil compaction were the leading drivers for reduced biocrust cover, while precipitation was not associated Second-growth forests supported anequally spaced biocrust cover, while in old-growth-forests biocrust cover was patchy. Disturbance reduced biocrust growth by two thirds and carbon sequestration by half. In synthesis, biocrusts increase soil organic carbon (SOC) in dry forests and as they double the SOC content in disturbed areas, may be capable of counterbalancing disturbance-induced soil degradation in this ecosystem. As they fix and fertilize depauperated soils, they may play a substantial role in vegetation regeneration in the human-modified Caatinga, and may have an extended ecological role due to the 
ever-increasing human encroachment on natural landscapes. Even though biocrusts benefit from human presence in dry forests, high levels of anthropogenic disturbance could threaten biocrust-provided ecosystem services, and call for further, in-depth studies to elucidate the underlying mechanisms.

Keywords: biological soil crusts, Caatinga, dry forest, exotic goats, human disturbances, soil organic carbon

\section{INTRODUCTION}

Biological soil crusts (hereafter referred to as "biocrusts") are communities consisting of photosynthetic (i.e., cyanobacteria, eukaryotic algae, lichens, and bryophytes) and non-photosynthetic organisms, such as heterotrophic bacteria and microfungi (Chamizo et al., 2013), covering around $12 \%$ of the Earth's terrestrial surface (RodriguezCaballero et al., 2018). As light dependent associations, they colonize the topsoil layer, where they aggregate soil particles via organic exudates and filamentous structures (Belnap and Büdel, 2016). While biocrusts cover a wide range of latitudes, from tropical to temperate and polar ecosystems (Belnap et al., 2001), they are particularly abundant across arid and semiarid regions, where vascular plants are not able to outcompete them (Belnap and Lange, 2013). Across suitable habitats, they can cover up to $100 \%$ of the terrestrial surface throughout the year (Kleiner and Harper, 1972).

Biocrusts have been identified as a key ecological component across many arid and semi-arid regions regarding biodiversity, ecosystem functions. They promote both primary and secondary succession and drive many ecological processes associated to early communities, such as biogenic weathering, soil development, nutrient uptake, and water balance (Belnap, 2001a; Chamizo et al., 2016). In bare soil spots, biocrusts follow a successional process initiated by cyanobacteria and algae, which favor the subsequent establishment of lichens and bryophytes (Belnap, 1995, 2001a). In this perspective biocrusts can facilitate, inhibit or have neutral effects on succession in vascular plant communities (Zhang et al., 2016), thus acting as ecosystem engineers. Biocrusts have been proposed to affect nutrient availability for vascular plants by fixing considerable amounts of nitrogen and carbon, enhancing phosphorous availability and reducing nutrient leaching through soil profiles (Elbert et al., 2012; Barger et al., 2016; Sancho et al., 2016). Due to their carbon and nitrogen fixing abilities, biocrusts have been found to be major players of the global nitrogen cycle and also affect the global carbon cycle (Elbert et al., 2012). Moreover, biocrusts improve soil aggregation, stability and porosity (Belnap, 2006; Castillo-Monroy et al., 2011) largely influencing soil attributes, such as moisture, hydrology and susceptibility to erosion (Bu et al., 2015; Belnap and Büdel, 2016). In addition to soil conditions and nutrient budgets, these organisms can directly affect seed germination of vascular plants, either positively or negatively, indicating that biocrust-mediated processes have relevance beyond simple soil development (Deines et al., 2007; Song et al., 2017).
Overall, biocrusts are composed of mainly slow-growing organisms highly sensitive to their close environment, including soil attributes, microclimatic conditions, and vascular plant communities. In addition to a potential competition for water, nutrients and light, vascular plants provide shaded habitats, and cause litter deposition on biocrusts, what has been considered a negative effect on biocrust colonization, performance and development toward late successional stages (Boeken and Orenstein, 2001; Berkeley et al., 2005). Biocrusts are also sensitive to human disturbances such as trampling by livestock (Condon and Pyke, 2018), soil degradation (Belnap and Gillette, 1998) and invasion by vascular plants (Belnap et al., 2006). Disturbed biocrusts usually experience changes in their physiological performance, taxonomic and ecological composition (Concostrina-Zubiri et al., 2014; Mallen-Cooper et al., 2018), which often represents a retrogressive succession from late (abundant lichens and bryophytes) to early successional stages (only cyanobacteria). As biocrust-mediated processes and services depend on the successional stage, human impacts can deplete them (Belnap, 1995, 2006). To provide an example, trampling by livestock can deteriorate biocrusts, causing soil degradation and a cascade of effects such as increased wind erodibility (Belnap et al., 2007), loss of key ecosystem processes like water infiltration (Chamizo et al., 2016), or favoring exotic plant invasion (Eldridge et al., 2010). In synthesis a myriad of interconnected variables drive biocrust spatial organization, performance, diversity, successional dynamics, and related services and impacts.

Research about the presence of biocrusts, their taxonomic composition and functional role in different habitats as well as their susceptibility to disturbance have initially been concentrated in arid and semiarid regions (Belnap et al., 2001). In most situations, there is a clear climatic limitation to vascular plants, implying that the relationships between biocrust and vascular plants can't be properly assigned as well as the role played by biocrusts on successional trajectories or vegetation dynamics beyond biocrust succession itself (Duane Allen, 2010). In fact, little attention has been devoted to tropical ecosystem dominated by vascular plants, such as dry forests, where according to theory and the state of research, biocrusts are not expected to be either abundant or ecologically relevant (Belnap et al., 2001; Maestre and Cortina, 2002; Seitz et al., 2017). To the best of our knowledge, there are only two studies on biocrusts in dry tropical forests (Maya and López-Cortés, 2002; Büdel et al., 2009) and apparently South America has been entirely overlooked in the context of biocrust research (Büdel et al., 2016). This scientific negligence may be partly due to the relative recency of global change phenomena. In fact, most of the tropical 
forest landscape is moving toward human-modified landscapes, usually represented by the establishment of land-use mosaics including active and old crop fields, pasture lands and patches of native forests (Tabarelli et al., 2010). This is particularly true in the Caatinga dry forest of northeast Brazil, the largest and one of the most species-rich seasonally dry tropical forests worldwide (Silva et al., 2017). Slash-and-burn agriculture and free-ranging goat/cattle has transformed the old-growth forest into a temporally dynamic mosaic consisting of old fields (i.e., abandoned crop or pasture fields), regenerating forest patches of varying ages and remaining old-growth forest patches at the landscape spatial scale (Tabarelli et al., 2017). This dynamic mosaic probably offers at least temporal windows of opportunity for biocrusts (i.e., open or sun-exposed habitats) with their spatial and ecological organization and potential impacts and services largely mediated by livestock and land use dynamics.

The effects of biocrust diversity and structure on dry tropical forests remains unstudied, especially with respect to ecosystem service provision, as for example carbon sequestration and soil fertilization. Soil organic carbon (SOC) accumulation can be considered an especially important ecosystem service for the naturally poor soils of the Caatinga (Tiessen et al., 1998). SOC is connected to numerous ecosystem functions upon which humans depend in the Caatinga, so that changes will have immediate consequences for the local population (Thomas, 2012). As in other drylands, SOC in the Caatinga is concentrated in the uppermost centimeters (Schulz et al., 2016) and therefore very sensitive to disturbance (Althoff et al., 2018). As this corresponds with the biocrust stratum, their presence might have a great impact. In drylands and areas at the stage of primary succession, such as in the Caatinga after land abandonment, SOC sequestration is mediated mainly by biocrusts (Lange, 2001; Thomas et al., 2011; Thomas, 2012). Possible positive effects of soil fertilization by biocrusts could be lost in the future, as the Caatinga is highly threatened by climate change and land use and land-use-driven reductions in SOC stocks have been reported for biocrusts (Thomas et al., 2011). The Caatinga is poorly understood in terms of biogeochemical cycling in general (Moura et al., 2016; Althoff et al., 2018) but more so for biocrust influence. Nonetheless, because of its size it may play an important role in global nutrient cycles and could act as a potential sink for atmospheric $\mathrm{CO} 2$.

The climate of dry forests in general should offer a suitable habitat for biocrusts (Rodriguez-Caballero et al., 2018), but have never been investigated for their presence or ecosystem services there. As has been known from studies worldwide, biocrusts can provide essential ecosystem services and are responsible for ecosystem integrity in many different habitats. Therefore, we aimed to investigate if biocrusts are an abundant component of dry forests and if they provide ecosystem services essential to the survival of a dry forest under human pressure, using the Caatinga as an exemplary forest biome. Here we present a baseline study on the occurrence, diversity, and ecological role of biocrusts inhabiting a human-modified landscape of the Caatinga dry forest in northeast Brazil. Biocrusts and drivers of biocrust organization at landscape scale were systematically recorded across a network of 34 permanent plots covering a wide range of land use from regenerating forest stands following slash-and-burn agriculture to old-growth forest patches. We expected that (1) biocrust cover, (2) taxonomic composition and (3) successional stage of biocrusts will be affected by forest successional stage (regenerating vs. old growth), litter cover (as a proxy of competition with vascular plants for light), precipitation patterns, goat trails/feces, and soil compaction Additionally, we investigate the impact of human disturbance and variable annual rainfall patterns on the ecosystem service of carbon sequestration and biocrust growth. We expected that human disturbance would severely limit the ability of biocrusts to capture/ store carbon by changing the species composition of the biocrust and their growth- We also expected that the reduction of SOC in biocrusts, induced by multiple low rain years could be canceled out by a single strong precipitation year. We highlight the unexpected diversity supported by biocrusts and the complex relationships between biocrusts and human disturbances, particularly how biocrusts can benefit from, but also potentially affect forest resistance and resilience across human-modified landscapes.

\section{MATERIALS AND METHODS}

\section{Study Area}

This study was carried out in the Catimbau National Park, a human-modified landscape of the Caatinga dry forest in northeast Brazil, with a predominance of Cactacea, Euphorbiaceae, and Fabaceae (Rito et al., 2017). The 607$\mathrm{km}^{2}$ landscape consists of a vegetation mosaic, resulting from the presence of small farmers devoted to slash-and-burn agriculture and livestock grazing (Tabarelli et al., 2017). Active and abandoned crop fields, second-growth forest patches of varying ages, and old-growth forests prevail. All vegetation types are exposed to chronic anthropogenic disturbance through firewood and forage collection, timber exploitation and livestock browsing (Arnan et al., 2018; Souza et al., 2019). Canopy cover never achieves $80-90 \%$ (M. Tabarelli personal information and Figure 1A). Soil is composed of sedimentary, deep lithosols with quartz sands, with the presence of sandstone outcrops; soils are naturally unfertile with $\mathrm{pH}$ around 4.5 (SNE, 2002). The regional climate is semi-arid $(<0.65$ precipitation/ potential evapotranspiration) with an annual temperature of $23^{\circ} \mathrm{C}$ (Sampaio, 1995). In Catimbau, annual rainfall varies between 480 and $1,100 \mathrm{~mm}$ across the landscape, with rain concentrated between March and July (water deficit between August and February; SNE, 2002) and high spatial and temporal variations, including droughts lasting more than a year (Sampaio, 1995; Rito et al., 2017).

\section{Human Disturbance and Biocrust Spatial Organization}

To investigate the spatial distribution and organization of biocrusts at the landscape level we adopted a sampling design based on $34 \times 0.1 \mathrm{~m}^{2}$-permanent plots as follows: 19 oldgrowth forest plots and 15 secondary growth forest stands with stands ranging from 5 to 70 years after land abandonment; i.e., regenerating stands of varying ages and vegetation structure from almost bare-soil plots up to well-developed forest achieving over 


\section{A}

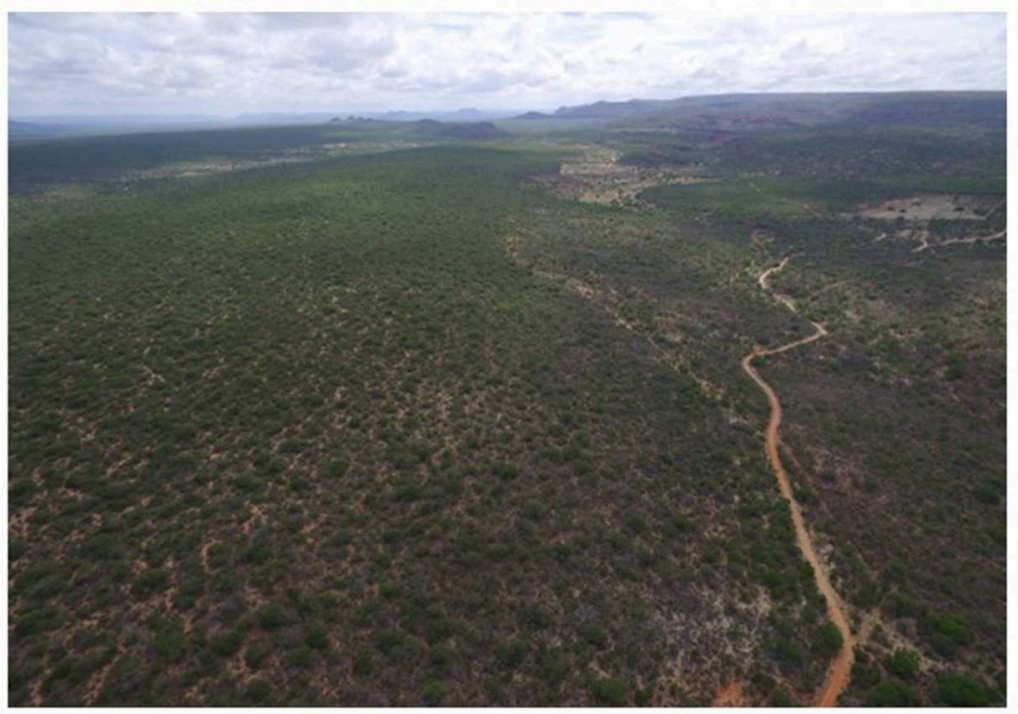

B
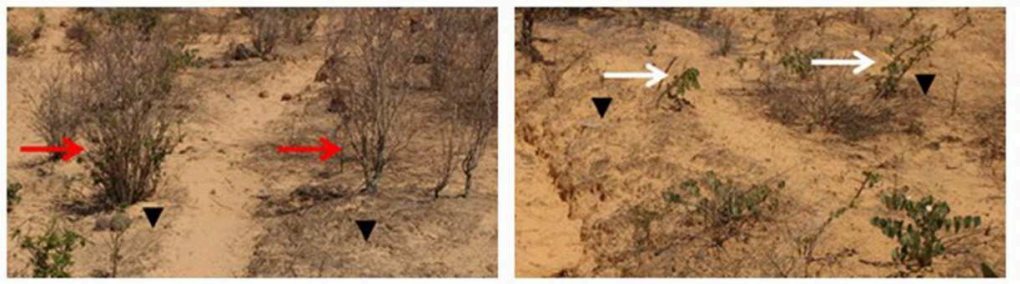

D
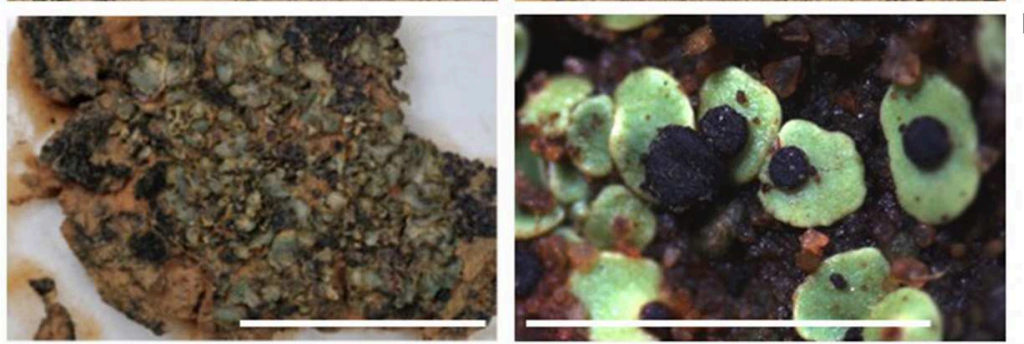

$\mathbf{F}$
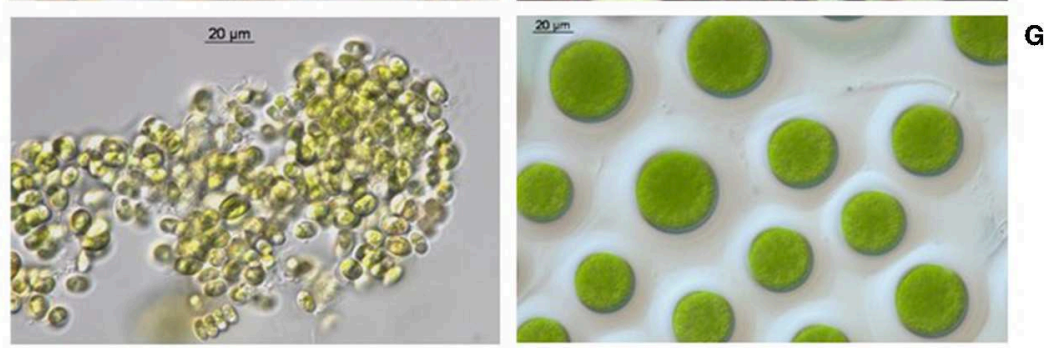

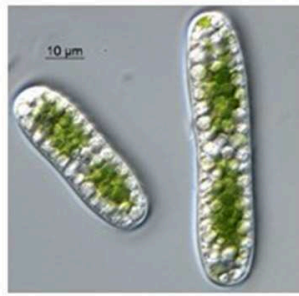

H

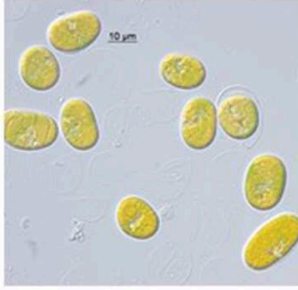

I

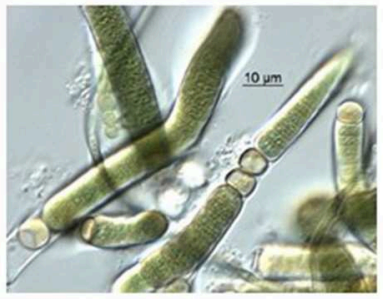

J

FIGURE 1 | Biocrusts of the Caatinga dry forest in the Catimbau National Park, northeastern Brazil. Overview of the canopy openness in old-growth forests with agricultural farmlands in the background (photo courtesy of Jens Brauneck, University of Kaiserslautern) (A). Trampling paths of goats left in the otherwise closed 
FIGURE 1 | biocrust cover (B) as well as association of biocrusts with vascular plants (C); shrubs marked with a red arrow Croton argyrophylloides (B) and shrubs marked with a white arrow Jatropha mutabilis (C). In both images the crusts are dominated by dark cyanobacteria (Nostoc spp., Scytonema sp. and Microcoleus vaginatus) demarcated with black triangles. Light microscopic images of cyanobacteria and green algae isolates (F-J), as well as lichen species [in situ, (D,E); white bar represents $500 \mu \mathrm{m}$ ], new to biocrusts of South America and found in Catimbau National Park. Heppia conchiloba (D), Bibbya cf. albomarginata (E),

Scenedesmus sp. (F), Follicularia sp. (G), Cylindrocystis brebissonii (H), Scotelliopsis cf. rubescens (I), Macrochaete lichenoides (J).

$120 \mathrm{Mg} \mathrm{ha}^{-1}$ of aboveground biomass (Souza et al., 2019). Plots also covered a gradient of precipitation $(510-940 \mathrm{~mm}$ of annual rainfall) and of chronic human disturbance, particularly firewood collection and livestock browsing as detailed by Arnan et al. (2018) and Rito et al. (2017). We thus considered to have included a considerable habitat variation resulting from the old-growth forest encroachment by small farmers; i.e., a typical Caatinga human-modified landscape (Tabarelli et al., 2017). The 34 plots were sampled three times during a 12-mo period (August 2017 to July 2018), with plots being regularly sampled every 4 months.

Plots were sampled by adopting a square grid sizing 0.5 $\times 0.5 \mathrm{~m}\left(0.25 \mathrm{~m}^{2}\right)$ made of PVC tubes, subdivided with string into twenty-five cells of $0.1 \times 0.1 \mathrm{~m}\left(0.1 \mathrm{~m}^{2}\right)$. The grid was disposed on the ground every $10 \mathrm{~m}$, along two 50 $\mathrm{m}$-transects, summing up 10 grids per plot. Each plot was sampled three times during 1 year, with transects disposed at different spots inside the plot every sampling period. It resulted in a total of 1,020 grids; i.e., 34 plots sampled via 10 grids each of the three sampling periods. As grid-based variables we adopted: (1) biocrust cover, (2) cover by herbs and seedlings up to $50 \mathrm{~cm}$ tall, (3) ground litter biomass (kg ha-1), (4) goat dung pellets, (5) goat trail cover, and (6) soil penetrability. Biocrust cover was quantified using the point intercept method (Levy and Madden, 1933) adopting three succession-related categories: (a) cyanobacterial biocrust, (b) lichen biocrust, and (c) bryophyte biocrust. Biocrust cover divided into functional groups has long been implemented as a basic variable in biocrust ecology research (Eldridge and Rosentreter, 1999). The pointintercept method was also adopted to estimate plant and goat trail cover. Soil compaction was measured by a penetrometer produced with a sharp steel bar $1.5 \mathrm{~m}$ tall, which was thrown into a $32 \mathrm{~mm}$ PVC tube ( $1.5 \mathrm{~m}$ long) against the ground (Passos and Oliveira, 2004). Vascular plant cover, trampling by livestock and soil texture/consistency have been identified as key drivers of biocrust performance and occurrence (Belnap and Gillette, 1998; Condon and Pyke, 2018). In this context, forest successional stage (old-growth vs. regenerating stands), cover by herbs, and the amount of ground litter were considered as proxies of total vascular plant cover, while dung and trails by goats as proxy of disturbance. Additionally, mean annual precipitation amount per plot, calculated by WordClim data, was investigated, because water availability is an important driver for biocrust occurrence and succession (Belnap et al., 2006). To investigate the effect of successional stage of the vegetation on biocrust distribution further, for each plot frequency of biocrust occurrence was calculated based on all 30 grids per plot. The available environment for the occurrence of biocrusts presented great physical and biological heterogeneity. Across the 34 plots, ground litter ranged from $29.1 \mathrm{~kg}$ ha- 1 to $524.7 \mathrm{~kg} \mathrm{ha}^{-1}(195.4$ $\pm 120.3)$, the coverage by goat trails between 0 and $88.3 \%$
(39, $6 \pm 21.5)$, soil compaction (penetrability) between 3.8 and $17.7 \mathrm{~cm}(10.7 \pm 2.8)$, the amount of feces between 0.0 and 48 pellets $/ \mathrm{m}^{2}(16 \pm 14.4)$, herb cover between 0.0 and $54.5 \%(8.7 \pm$ $12.1)$, and precipitation ranging from 510 to $940 \mathrm{~mm}(748 \pm 145)$.

Finally, biocrust cover was also estimated via point-intercept grids into a network of long-standing goat trails crossing a degraded pasture field established after clearing a large patch of old-growth forest. This pasture field supported immense biocrust patches of Nostoc spp., Scytonema sp. and Microcoleus vaginatus (pers. obs. BB and MS), which were closely associated to small shrubs such as Croton argyrophylloides and Jatropha mutabilis. (Euphorbiaceae) (Figures 1B,C). We randomly selected 30 sampling points along a total of $100 \mathrm{~m}$ of goat trails (i.e., trail grids), at least $10 \mathrm{~m}$ apart from each other. Paired control grids were placed next to the trail grids ( $5 \mathrm{~m}$ at maximum) but clearly apart from goat trail influences. Point intercept measurements were carried out once in the beginning of the 2017-dry season.

\section{Taxonomic Identification and Microscopy}

In order to obtain a basic and rather qualitative understanding of the natural species richness of biocrusts occurring in the Catimbau landscape, including taxonomic and ecological groups, two non-systematic surveys were carried out, outside the 34 0.1 ha plots. First, biocrusts were actively searched in 10 sites, covering a wide range of habitat types representing different successional stages and degrees of disturbance, from abandoned crop and pastures to old-growth forest patches. The sites were chosen as distinctly differing successional stages and under different disturbance regimes, to represent the mosaic-like structure of the Caatinga vegetation. A basic understanding of biocrust presence in the Caatinga was gained and found species were taxonomically assigned. Samples were collected haphazardly by pressing inverted petri dishes $(\varnothing 10 \mathrm{~cm})$ into the biocrust and carefully detaching it from the soil matrix with the aid of a spatula. At the field site, biocrusts were identified to the lowest taxon possible using a $10 \mathrm{x}$ magnifying glass, and a light microscope $(400 \mathrm{x})$. Second, biocrusts of two study sites representing the extremes of the disturbance gradient (see soil organic carbon measurements) were identified, using a culturing approach following (Jung et al., 2018) for three samples at both sites. For each sample, $250 \mathrm{mg}$ of biocrust material was randomly picked from a natural sample (one petri dish) and incubated in $15 \mathrm{ml}$ liquid Bold's Basal Medium with soil extract (BBM; Bischoff, 1963) overnight. The samples were being shaken and allowed to settle for $30 \mathrm{~s}$, to remove floating particles. The supernatant was then added to $15 \mathrm{ml} \mathrm{BBM}$. This was repeated three times, resulting in $45 \mathrm{ml}$ sample in BBM medium. After centrifugation for $5 \mathrm{~min}$ at $1,000 \mathrm{rpm}$, the supernatant was decanted and the pellet resuspended in $250 \mathrm{ml}$ of double-distilled water, from which the samples were transferred to solidified 
BBM with soil extract, with two replicates for each sample. The cultures were kept in a culture cabinet at standard conditions used in our lab $\left(15-17^{\circ} \mathrm{C}\right.$, light-dark cycle of $16: 8 \mathrm{~h}$, light intensity of ca. 20-50 $\mu \mathrm{mol}$ photons $\mathrm{m}^{-2} \mathrm{~s}^{-1}$ ). The cyanobacterial and green algal colonies were examined with a light microscope (Axioskop, Carl Zeiss, Jena, Germany, $630 \mathrm{x}$ ) operated with Zeiss Axiovision software after 5, 12, and 17 weeks. The organisms from the cultures and field samples (also including bryophytes and lichens, were determined with taxonomic keys (e.g., Ettl and Gärtner, 1996; Komárek and Anagnostidis, 1998, 2005), as well as own (B. Büdel) and external expert knowledge (K.C. Pôrto, UFPE).

\section{Soil Organic Carbon Sequestration and Biomass Increase}

For this investigation, we chose two case study sites representing contrasting successional stages of biocrust communities along the disturbance gradient of the Catimbau National Park (referred to henceforth as "Early site" and "Late site"). While the Early site is an actively managed Cashew plantation (3.96 ha in size), the Late site (2.64 ha) represents former agricultural land, mainly pasture, on which a young secondary forest with shrub vegetation developed following abandonment ca. 40 years ago (details see Table S1). Both sites were investigated for biomass increase and carbon sequestration before the rainy seasons of the years 2017 and 2018. Since the biomass increment of biocrusts of a given year should primarily reflect growth conditions of the previous years, the status of the 2017 biocrust represents 2016, which was a drought year, while 2018 represents 2017, which was an unusually wet year (see Table S2). Biocrust coverage was studied in March 2017 only.

To explore the impact of biocrusts on SOC and assess their biomass contribution, bare soil $(n=16)$ and biocrust $(n=45)$ samples were collected from random biocrust and control patches of differing size (biocrusts: 0.0035-1.2462 $\mathrm{m}^{2}$; control: $0.0067-0.5519 \mathrm{~m}^{2}$ ), in both study sites for both years. Distance between the patches and between the controls was always $>5 \mathrm{~m}$. For each patch a cylinder of $1 \mathrm{~cm}$ depth, which is adequate for biocrusts (Maestre et al., 2013), and $2.5 \mathrm{~cm}$ diameter was pushed into the biocrust 7 times and thereafter mixed, to extract enough material for the analyses. The biocrust samples were covered $100 \%$ by cyanobacterial biocrusts in both sites; bryophyte and/or lichen presence was avoided to ensure sample homogeneity. Cyanobacterial biocrusts are of key interest, as they are the most dominant group at both sites and throughout the whole national park (Figure 2B). In the laboratory, the samples were separated into two fractions, one for quantifying biomass and growth using the amount of chlorophyll $a$ as biomass proxy for autotrophic biocrusts (e.g., Johnson et al., 2012), the other for soil organic carbon (SOC) measurements.

To assess biocrust biomass and, hence, growth between 2017 and 2018 for both case study sites, chlorophyll $a$ was extracted with dimethyl sulfoxide (DMSO; Ronen and Galun, 1984) and determined spectrophotometrically. For this, each sample was mixed with a scoop tip of $\mathrm{CaCO}_{3}$, covered in DMSO, and heated in a water bath at $65^{\circ} \mathrm{C}$ for $45 \mathrm{~min}$ twice. After centrifugation at $2000 \mathrm{rcf}$ for $10 \mathrm{~min}$, the optical density (OD) of each sample was measured with a spectrophotometer (UV/Vis Spectrometer LAMBDA 35, Perking Elmer Inc. Waltham, MA, USA) at two wavelengths: 700 and $665 \mathrm{~nm}$. Chlorophyll content was then calculated for each sample with the following equation (Arnon, 1949): Chlorophyll $a(\mu \mathrm{g})=\left[\left(\mathrm{OD}_{665} * \mathrm{OD}_{700}\right) * 12.19\right] * \mathrm{~mL}$ DMSO, where $\mathrm{OD}_{700}$ is the unspecific absorption and $\mathrm{OD}_{665}$ the absorption peak for chlorophyll $a$.

SOC content was determined by the loss on ignition method (LOI) described by Black (1965). Samples were prepared following the protocol of Throop et al. (2012), by sieving them through a $2 \mathrm{~mm}$ sieve to exclude stones, passing other aggregates through the sieve, and discarding the skeletal fraction. About $10 \mathrm{~g}$ were ground finely in an oscillating mill for subsequent ignition at $550^{\circ} \mathrm{C}$ for $2 \mathrm{~h}$. SOC stock was calculated according to Schulz et al. (2016) to provide results comparable to those of other surveys: SOC stock $\left[\mathrm{g} \mathrm{cm}^{-2}\right]=$ bulk density $\left[\mathrm{g} \mathrm{cm}^{-3}\right] * \mathrm{SOC}$ content $\left[\mathrm{g} \mathrm{kg}^{-1}\right] *$ depth $[\mathrm{cm}]$.

\section{Data Analysis}

For the assessment of biocrust cover in 34 plots across the park landscape, the point-intercept data from three sampling campaigns were collapsed into a single sample per plot (i.e., 30 grids per plot). Accordingly, the number of recorded cells containing biocrusts, goat trails or vascular plants was transformed into a percentage of the total cells evaluated in the plot (i.e., 30 grids vs. 25 cells per grid per plot). The data were successfully tested for normal gaussian distribution and homogeneity of variance prior to statistical analyses. Pearson's correlation coefficient was used to test potential relationships among explanatory variables and because of that we finally adopted: goat trail cover (\%), fine litter biomass $(\mathrm{kg}$ $\mathrm{ha}^{-1}$ ), soil compaction (penetrability in $\mathrm{cm}$ ) and precipitation gradient ( $\mathrm{mm}$ ). Generalized linear mixed models (GLMM) were performed to examine potential effects of these variables plus forest successional stage (old-growth vs. regenerating stands) on cover of: (1) total biocrust, (2) cyanobacterial crust, (3) lichen-, and (4) bryophyte-dominated biocrust, with plot as the random factor and LME as the estimation method. All analyzes were performed in the $\mathrm{R}$ 3.0.0 programming language environment using the packages nlme, stats, mlmRev, lme4, gplots, psych and Rcmdr. Additionally, the difference in biocrust frequency between the two vegetation successional stages was investigated with a global $\chi^{2}$ test, followed by a pairwise post hoc test. The $p$-value was adjusted by Bonferoni correction. The analysis was performed using Statistica (Statistica, version 10, StatSoft, Inc., Palo Alto, CA, USA).

For the differences in biocrust-related biomass increase and SOC sequestration at the two case study sites, a multifactorial ANOVA was used, with site (succession), study year (precipitation) and bare soil vs. biocrust (biocrust effect) as explanatory variables. The data were normally distributed and homogenous in variance. The analysis was also performed using Statistica. 


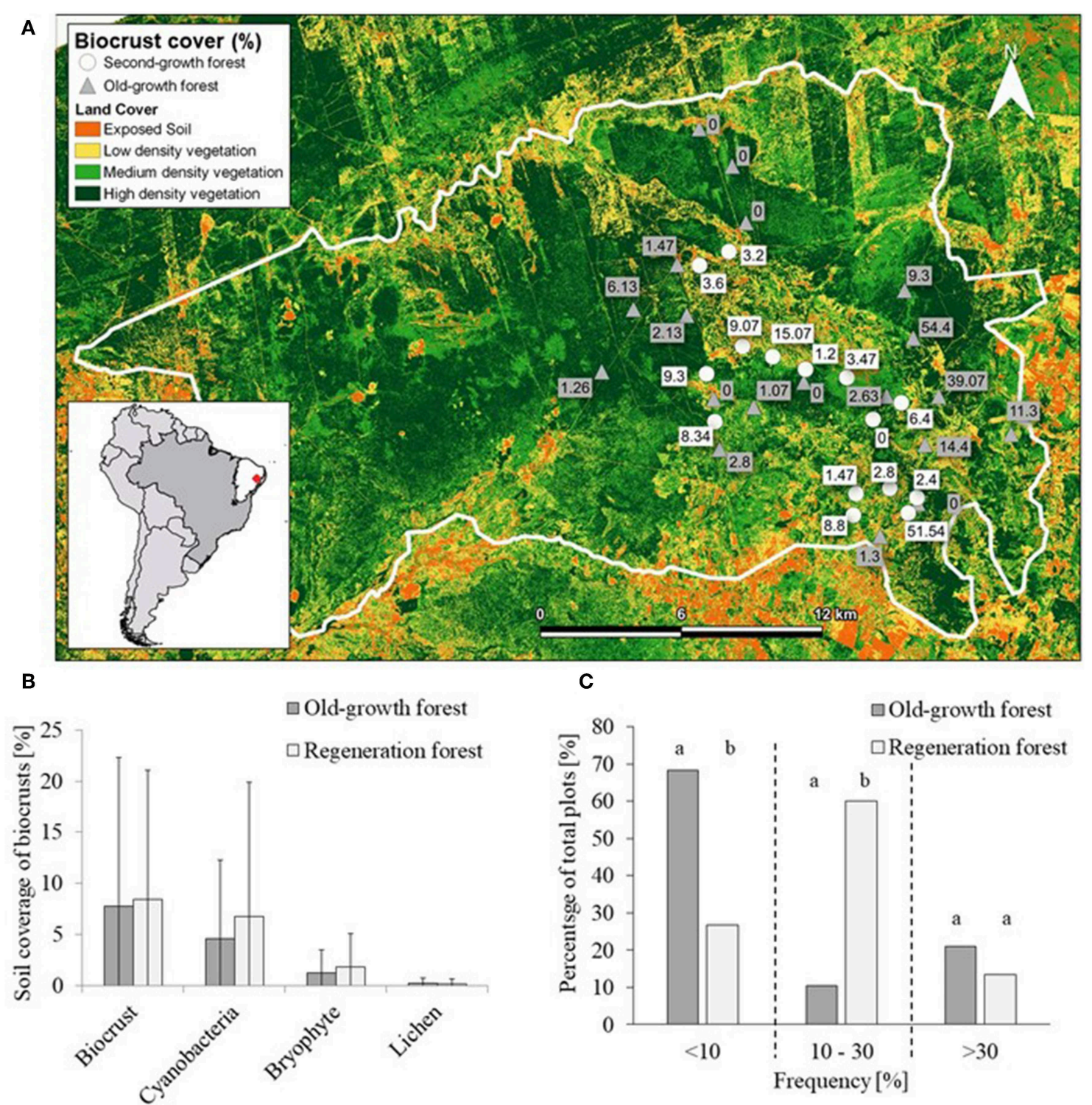

FIGURE 2 | Coverage and frequency of biocrust communities in the Catimbau National Park, northeastern Brazil. Map representing vegetation density (generated with rapideye bands reflectance by Davi Jamelli, Federal University of Pernambuco) and average cover of biocrusts inside the 34 permanent plots (A). Difference in mean biocrust coverage $( \pm \mathrm{SD}$ ) between two successional stages of vegetation (old-growth forest $n=19$; regeneration forest $n=15$ ), separated into functional groups of biocrusts (B). Proportion of plots with low (<10\%), intermediate (10-30\%) and high (>30\%) frequency of biocrust occurrence in the two forest successional stages (C). Frequencies generally differed between old-growth and regeneration forest (global $\chi^{2}=9.55$, df $=2, p=0.008$ ); for pairwise test results see text. Significant differences between old growth and second growth forest are denoted with different letters above the bars following a pair wise chi-square post hoc test ( $p<0.05)$.

\section{RESULTS}

In total, our biocrust surveys including the active search across 10 sites, random sampling in all 34 permanent plots, and the culturing approach using samples from the two case study sites, resulted in 50 biocrust taxa throughout Catimbau National Park. More precisely, 19 biocrust organisms were identified to the species level, 33 to the genus, and one taxon to the family. A total of 23 taxa have not been reported yet for South America, and hence the Caatinga in the context of biocrust research (Table 1 and Figures 2D-J). They include cyanobacteria (three taxa), green algae (nine taxa), lichens (seven taxa) and bryophytes (four taxa). The cyanobacteria Nostoc spp., Scytonema sp., the liverworts Riccia sp. 1 and sp. 2, and the moss Bryum exile were the most frequent taxa. While the number of cyanobacteria, bryophytes and green algae species was similar under contrasting rainfall and disturbance intensities, more lichen species occurred in wetter areas (Table 1).

At the plot spatial scale $(n=34)$, biocrusts of all three successional stages were recorded throughout the year, although in six plots (17.6\%), no biocrust was recorded during the three sampling campaigns (Figure 2A). However, most of the plots 
TABLE 1 | Biocrust taxa found in the National Park Catimbau, northeastern Brazil, roughly assigned to their occurrence in high and low precipitation and disturbance regimes.

\begin{tabular}{llll}
\hline Species & $\begin{array}{l}\text { High rainfall } \\
(>748 \mathrm{~mm})\end{array}$ & $\begin{array}{l}\text { Low rainfall } \\
(\leq 748 \mathrm{~mm})\end{array}$ & $\begin{array}{l}\text { High } \\
\text { disturbance }\end{array}$ \\
\hline
\end{tabular}

\section{Cyanobacteria}

Aphanocapsa sp.

Calothrix sp.

Chroococcidiopsis sp.

Gloeocapsa sp.

Leptolyngbya sp.

Macrochaete lichenoides

Microcoleus vaginatus

Nostoc edaphicum

Nostoc ellipsoides

Nostoc sp. 1

Nostoc sp. 2

Oscillatoria sp.

Pseudophormidium sp.

Schizothrix sp.

Scytonema hyalinum

Scytonema sp. 1

Stigonema sp.

Tolypothrix sp.

\section{Green algae}

\section{Chlorella sp.}

Cylindrocystis brebissonii

Desmococcus sp.

Follicularia sp.

Heterococcus sp.

Klebsormidium sp.

Macrochloris multinucleata

Neochloris sp.

Scenedesmus sp.

Scotiellopsis rubescens

Spongiochloris sp.

Stichococcus sp.

Trebouxiophyceae

Green algae sp. 1

Green algae sp. 2

Green algae sp. 3

Green algae sp. 4

\section{Mosses}

Bryum argenteum

Bryum exile

Campylopus pilifer

Fissidens submarginata

Tortela humilis

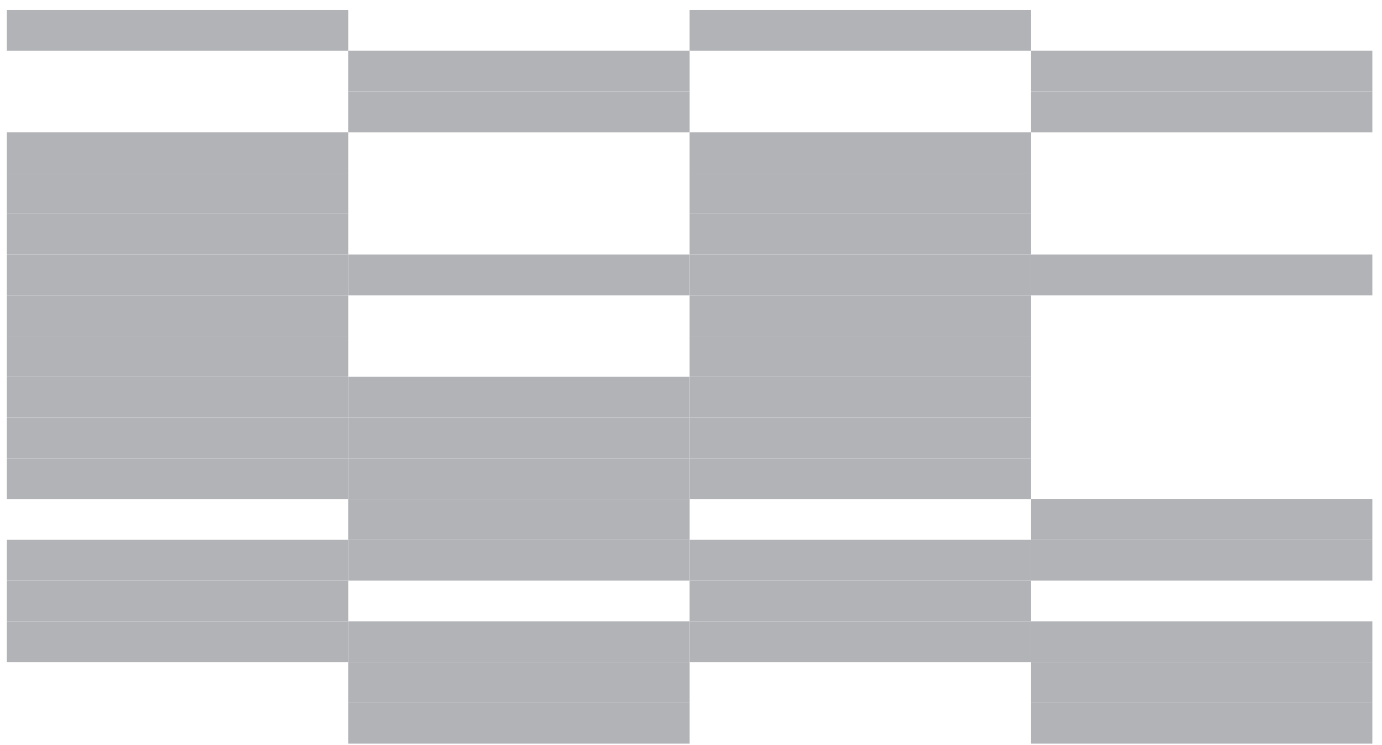

\section{Liverworts}

Riccia sp. 1

Riccia sp. 2

Riccia vtialii
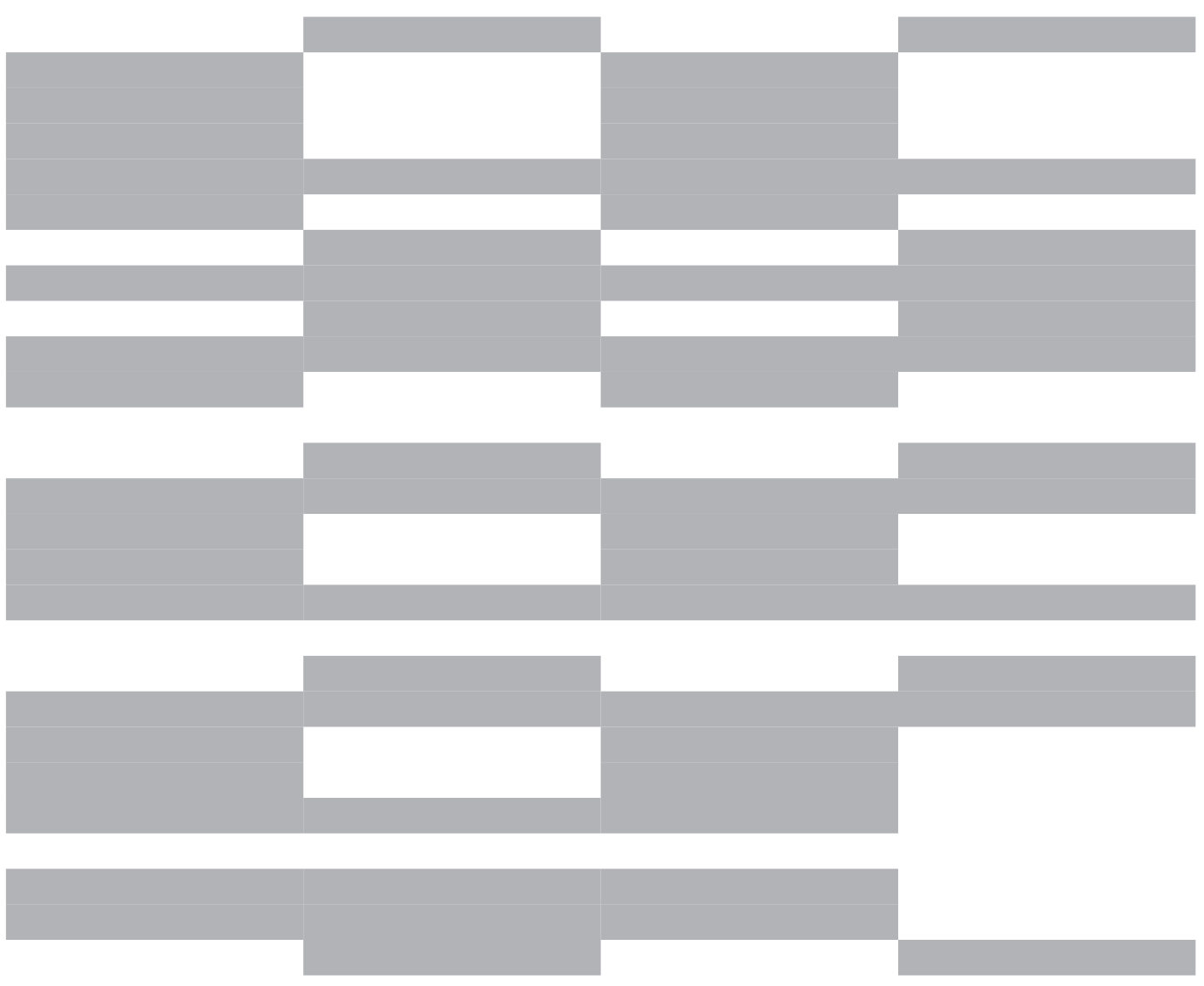

(Continued) 
TABLE 1 | Continued

\begin{tabular}{llll}
\hline Species & $\begin{array}{l}\text { High rainfall } \\
(>748 \mathrm{~mm})\end{array}$ & $\begin{array}{l}\text { Low rainfall } \\
(\leq 748 \mathrm{~mm})\end{array}$ & $\begin{array}{l}\text { High } \\
\text { disturbance }\end{array}$ \\
\hline
\end{tabular}

\section{Lichens}

Buellia sp.

Cladonia foliacea

Cladonia verticillaris

Heppia conchiloba.

Lecidea sp.

Peltula michoacanensis

Bibbya cf. albomarginata

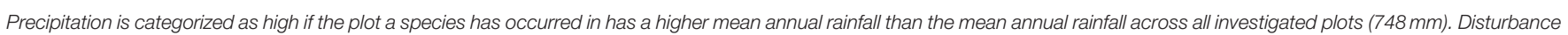

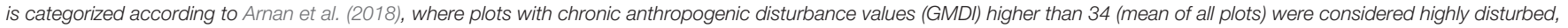

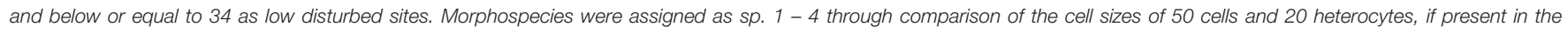

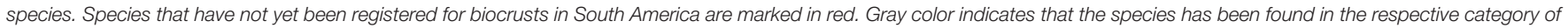
disturbance or precipitation regime.

(44.4\% of 27 plots with biocrusts recorded) supported only cyanobacteria biocrusts (i.e., initial biocrusts), particularly those dominated by Scytonema sp. Only $7.4 \%$ of plots exhibited lichen biocrusts, particularly Bibbya cf. albomarginata (intermediate successional biocrusts), while $48.2 \%$ had bryophytes recorded; i.e., late biocrusts with mosses and liverworts. Total plot cover of biocrusts ranged from 0 to $54.4 \%(8.1 \pm 13.6$; mean \pm standard deviation) with no difference between successional stages of the vegetation $\left[t_{(34)}=-0.146, p=0.885\right]$ (Figure 2B). Frequency of biocrust coverage however, did show a difference between the two successional stages of the forest. Regenerating forest supported more plots with moderate biocrust frequency between 10 and $30 \%\left(\chi^{2}(1 ; N=11)=9.38, p=0.002\right]$. On the other hand, more patches of low biocrust frequency $(<10 \%)$ where found in old-growth forest $\left[\chi^{2}(1 ; N=17)=5.85, p=\right.$ 0.016] (Figure 2C). Plots with high crust frequency (>30\%) were seldomly and evenly encountered across forest successional types $\left[\chi^{2}(1 ; N=6)=0.34, p=0.56\right]$. Considering only the 27 plots in which biocrusts occurred, cover by cyanobacterial biocrusts (initial) ranged from 0.13 to $53.1 \%(7.5 \pm 11.5)$, lichen biocrust (intermediate) between 0.26 and $1.8 \%(1.24 \pm 0.6)$ and bryophyte biocrust (late) between 0.11 and 9.3\% (3.8 \pm 3.2$)$.

Across plots, biocrust cover decreased with (1) greater coverage of goat trails, (2) higher fine litter biomass, and (3) higher soil penetrability (Table 2, Figures 3A-C), while other factors such as precipitation, herb cover, or feces showed no effects. The cyanobacteria biocrust responded negatively to litter (Figures 3D-F, Table 2), while no significant relationship was found between the coverage by lichen biocrusts and the explanatory variables (Figures 3G-I, Table 2). Bryophyte biocrusts negatively responded only to goat trails (Figures 3J-L, Table 2), but positively to soil compaction. The successional stage of the vegetation (regenerating vs. old-growth forest) did not directly affect biocrust coverage, but its interaction with the soil compaction affected both the total cover of biocrusts and the cover of bryophytes, this interaction being stronger across old-growth forests (Table 2). Finally, long-standing goat trails supported only $6.3 \pm 6.1 \%$ of biocrust cover, while spots of degraded pastures reached $23.0 \pm 2.6 \%$ of the soil surface covered by biocrusts $\left[t_{(30)}=13.5, \mathrm{df}=39.50, p<0.0001\right]$.

SOC content in bare soil (control) was equal for both case study sites (Tukey posthoc: $\mathrm{p}_{2017}=0.58 ; \mathrm{p}_{2018}=0.56$ ). Therefore, site differences between biocrusts are solely due to the successional status of the biocrust communities themselves $\left[F_{\text {succession }(1,236)}=71.1, p=0.000\right]$. SOC content roughly doubled in biocrusted soils compared to bare ground (from 6.04 and $8.70 \mathrm{~g} \mathrm{~kg}^{-1}$ to 10.67 and $19.82 \mathrm{~g} \mathrm{~kg}^{-1}$, respectively for Early and Late site) $\left[F_{\text {biocrust effect }(1,236)}=145.55, p=0.000\right]$, independent of site and precipitation. Likewise, SOC doubled in late as compared to early successional biocrusts (10.67 to $19.82 \mathrm{~g} \mathrm{~kg}^{-1}$ ) (Tukey posthoc: $\mathrm{p}_{2017}=0.000 ; \mathrm{p}_{2018}=0.000$; Figure 4A). Precipitation did not show any effect on SOC, neither in biocrusts nor in control soils $\left[F_{\text {precipitation }(1,236)}=\right.$ 0.037, $p=0.85$, Figure 4A].

Likewise, the control soils of both case study sites had similar Chlorophyll a concentration as a proxy of biomass of autotrophic biocrusts (Tukey posthoc: $\mathrm{p}_{2017}=1.000 ; \mathrm{p}_{2018}=$ 0.999 ), so that differences are a result of biocrust successional status $\left[F_{\text {succession }(1,236)}=11.3, p=0.001\right]$. In the wet year, the presence of biocrusts increased the chlorophyll a content of top soil layers by more than 1,500-fold (from 0.0036 to $5.85 \mathrm{mg} \mathrm{m}^{-2}$ ) in the early successional crusts and 12-fold (from 1.25 to $15.82 \mathrm{mg}$ $\mathrm{m}^{-2}$ ) in late successional biocrusts (Tukey posthoc: $\mathrm{p}_{\text {early }}=0.04$; $\mathrm{p}_{\text {late }}=0.000$; Figure 4B) compared to bare soil. Biocrust presence in general showed a pronounced increase of chlorophyll a content in the soil $\left[F_{\text {biocrust }}\right.$ effect $\left.(1,236)=37.4, p=0.000\right]$. Precipitation had a strong effect on biocrust growth across the study years: From the drought year 2017 to the wet year 2018, chlorophyll a increased 7 times at the Early site (from 0.71 to $5.85 \mathrm{mg} \mathrm{m}^{-2}$ ) and 6.5 times (from 2.12 to $15.85 \mathrm{mg} \mathrm{m}^{-2}$ ) at the Late site $\left[F_{\text {precipitation }(1,236)}=27.9, p=0.000\right]$.

\section{DISCUSSION}

Our results suggest that human-modified landscapes of the Caatinga dry forest can support biocrust communities at different 


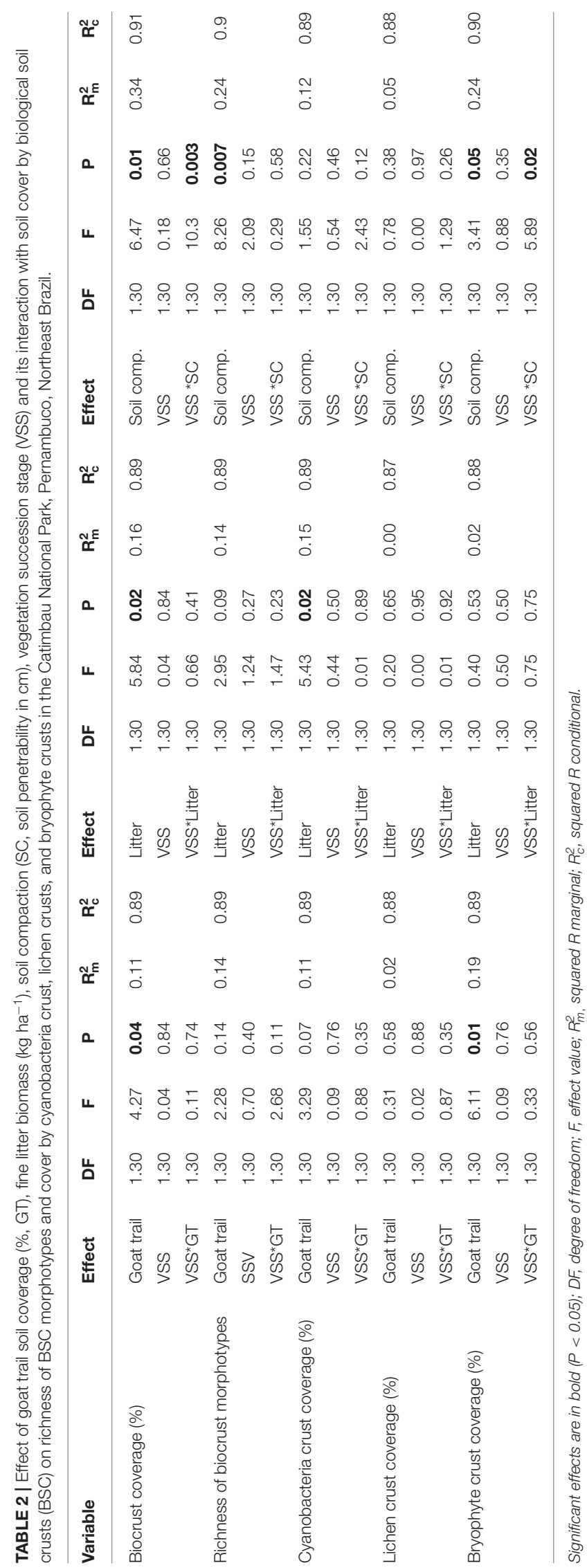

successional stages, with high taxonomic and ecological diversity. Biocrusts composed of at least 50 taxonomic groups occurred across numerous habitats-from abandoned farmlands to oldgrowth forests, although there was a predominance of initial biocrusts dominated by cyanobacteria. Bryophytes were the second most abundant group, while lichens were almost absent, although being the typically intermediate stage of succession in hot arid/semi-arid areas. Biocrusts covered a significant fraction of the soil surface $(8.1 \pm 13.64 \%$; mean \pm standard deviation of the biocrusts in the Catimbau National Park) throughout the year, with more than $50 \%$ coverage of cyanobacterial biocrusts in some areas. Biocrust communities benefited from reduced ground litter and little goat pressure, while forest successional stage and precipitation amount per se had no effect. They were potent carbon sequestering agents of dry forests and due to this fertilization effect could play a substantial role in forest regeneration. However, high levels of anthropogenic disturbance lead to a pronounced decrease in biocrust growth and SOC sequestration.

\section{Biocrust Composition and Diversity}

Conventionally, biocrusts are known to predominate in landscapes with little cover by vascular plants (i.e., arid and semi-arid regions dominated by sparse shrubs) and reduced human disturbances (Belnap et al., 2016; Ayuso et al., 2017). Our findings suggest that even in forest biotas, biocrusts can be ecologically/taxonomically diverse and abundant, particularly in the case of rural populations creating vegetation mosaics. Although comparisons across studies are difficult due to differences in sampling effort and geographic scale, the presence of 33 genera only in the Catimbau National Park suggests that the Caatinga supports a relatively diverse community at landscape scale. As an example, in Australia 86 genera were recorded considering 83 sites (Thompson et al., 2006) and more than 60 taxa were found across seven ecosystems in Africa (Büdel et al., 2009). Most taxa found exhibit a broad geographical distribution, occurring with high abundance across deserts and semi-deserts, e.g. Bryum (moss; e.g., Kidron et al., 2002), Riccia (liverwort; e.g., Eldridge and Tozer, 1996), Heppia (lichen, e.g., McCune and Rosentreter, 1995), Scytonema, Microcoleus and Nostoc (cyanobacteria; see Büdel et al., 2016), and Chlorella (green algae; e.g., Rosentreter and Belnap, 2001). The list of biocrust species was expanded by 23 taxa that have not yet been registered as biocrust members for the Caatinga, Brazil or South America and included cyanobacteria (e.g., Macrochaete lichenoides; Figure 1J), green algae (e.g., Cylindrocystis brebissonii; Figure $\mathbf{1 H}$ ), lichens (e.g., Heppia conchiloba; Figure 1D) and mosses (e.g., Fissidens submarginata).

The dominant functional group of biocrusts in the study landscape, independent of forest successional stage, was cyanobacteria and, occasionally, green algae, making up $79.3 \%$ of the biocrust-covered area. Cyanobacteria belong to the first colonizers of open soils and throughout the whole succession of a biocrust, are an important component of it (Weber et al., 2016). Both forest systems supporting mainly this biocrust type suggests that the development of later successional stages might be suppressed by irregular rainfall, vascular plant presence or 


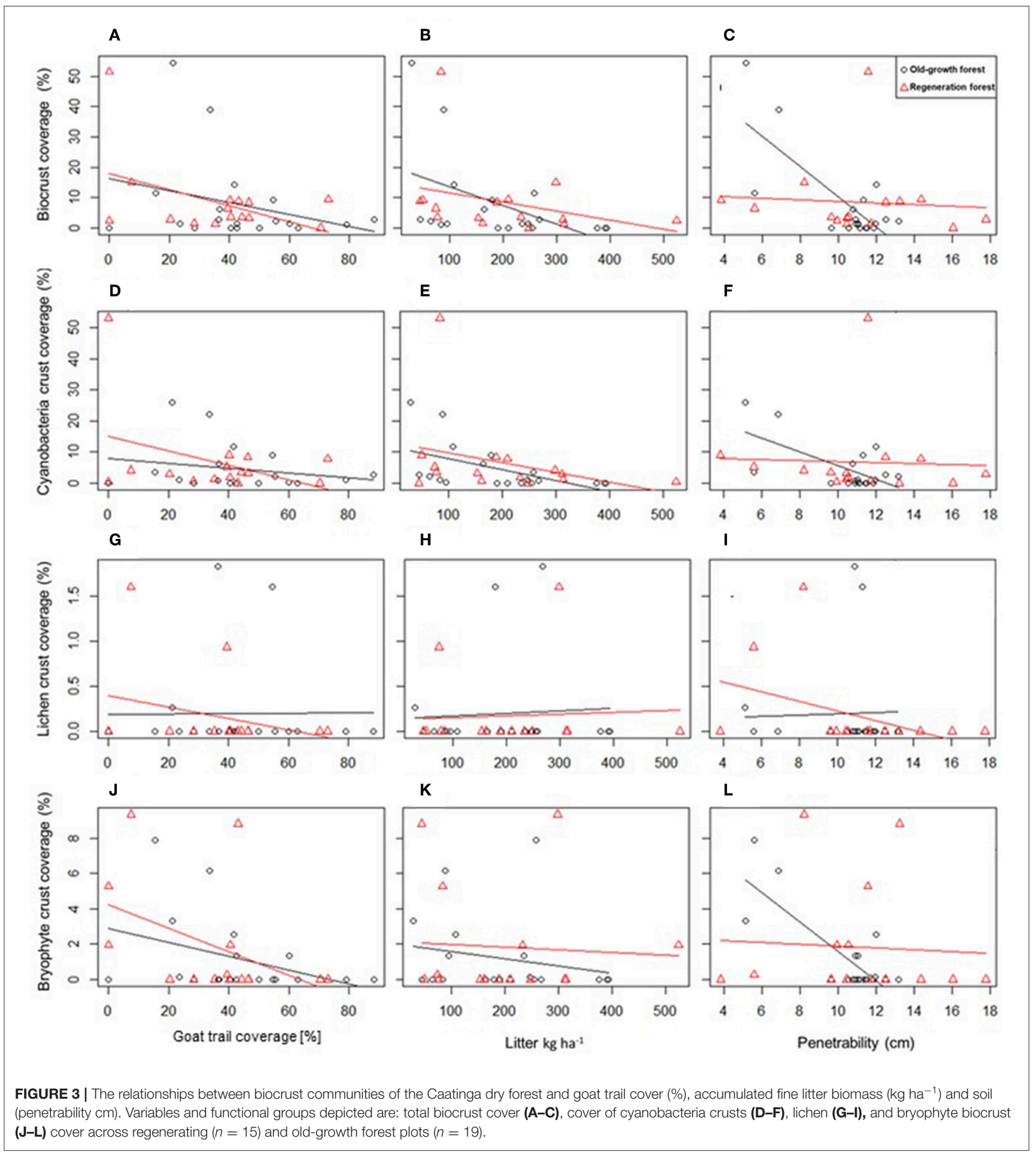

sandy soils. Bryophytes were the second most abundant group while still subdominant ( $18 \%$ of all biocrusts). The almost complete absence of lichen-dominated biocrust communities in every habitat independent of vascular succession in the study landscape $(2.7 \%)$ contrasts with our current understanding of biocrust succession in drylands (Seppelt et al., 2016; Weber et al., 2016), where lichens, especially of the genus Collema, form intermediate biocrust successional stages. The relative lack of lichens in the sedimentary Caatinga may be explained by the facts that they are heavily susceptible to trampling (e.g., Concostrina-Zubiri et al., 2014), dense litter cover (Briggs and Morgan, 2008) and don't grow well on coarse sand (Bowker et al., 


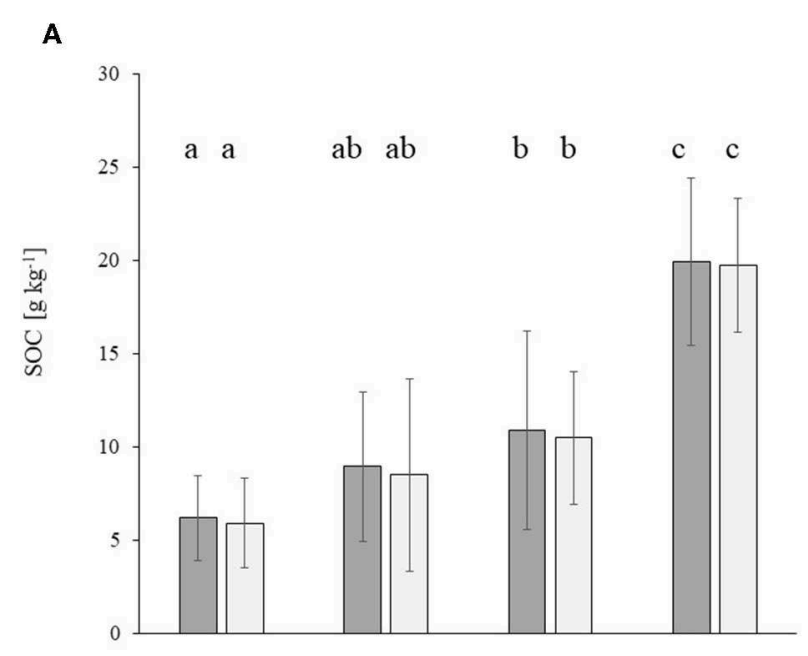

B

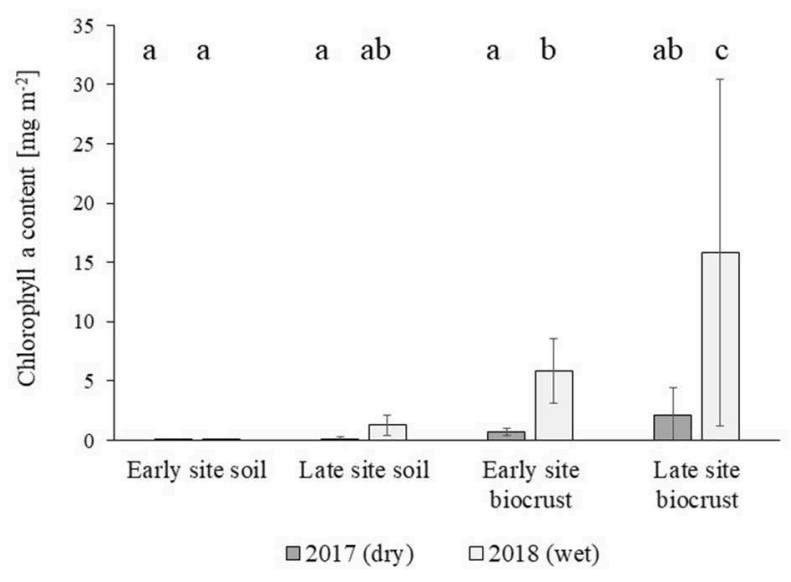

FIGURE 4 | Edaphic characteristics of topsoil layers in bare soils and biocrusts at early and late successional case study sites in the Catimbau National Park, northeastern Brazil. Depicted are means \pm SD of soil organic carbon content (A) and chlorophyll a concentration (B) in biocrusts $(n=45)$ and bare soil $(n=16)$. Measurements were done in a year following a drought period (2017) and after a very wet year (2018) (see material and methods for details). Significant differences between means are denoted with different letters above the bars following Tukey's post hoc test $(p<0.05)$.

2006). In fact, burial by sand or litter is known to kill lichens, green algae and smaller cyanobacteria (Campbell, 1979) but may promote bryophytes, as some species are able to push through a litter or recent dust layer (Marschall and Proctor, 2004). While we qualitatively observed a tendency for lichen species to occur in wetter areas with lower disturbance intensity, their low overall cover in the study likely compromised statistical power to detect drivers of lichen distribution.

\section{Biocrust Distribution and Anthropogenic Disturbance}

Biocrusts in (sub-)tropical forests have either been neglected entirely or described as a transient phenomenon associated to disturbances, such as treefall gaps, that disappear during forest succession (Seitz et al., 2017). This was not the case in the Caatinga, where biocrusts were present at every successional stage and reached similar coverage scores in old-growth and regenerating forests. Most plausibly, the Caatinga dry forest serves as a suitable habitat to biocrusts because light is not as limiting as in rainforests and other forest biomes. Even the oldgrowth forest permit the occurrence of biocrusts by providing relatively well-illuminated habitats. This is due to its low stature, low leaf area index, and high proportion of deciduousness (Pennington et al., 2009; Oliveira et al., 2013), thus reducing forest biomass and litter production; all attributes associated to a highly seasonal rainfall regime and a semiarid climate; i.e., reduced ecosystem productivity (Eamus, 1999). However, biocrusts benefited from human disturbance as the distribution of biocrusts in regeneration areas was less patchy than in oldgrowth-forests, where they may primarily occur because of the pronounced discontinuity of the canopy (see Figure 1A). As oldgrowth forests are converted into agricultural-forest mosaics, biocrusts spread over more illuminated habitats, such as old fields (abandoned crops and pastures) and second-growth forest stands of varying ages. Precipitation is usually advantageous for biocrust presence (Bowker et al., 2016) though it comes with the disadvantage of having to compete with vascular plants for light and space (Harper and Belnap, 2001; Thompson et al., 2006). Surprisingly and despite a strong rainfall gradient across the study landscape, precipitation did not show a significant impact on biocrust coverage. This may be explained by (1) the pronounced spatio-temporal patchiness of rainfall in the Caatinga region (Silva et al., 2017), (2) a high wet season rainfall allowing biocrusts to water-saturate and grow (saturating water content for biocrusts see e.g., Szyja et al., 2018), or (3) other factors adding noise to the biocrust distribution pattern. To provide an example, chronic anthropogenic disturbance, e.g., fuel wood collection, represents a continuous factor opening canopies at all regeneration stages, independent of precipitation amount, thus potentially altering biocrust cover and community composition. Similar results have been found by a recent study on the distribution of vascular plant biomass, which could be explained by a multitude of factors, except rainfall (Souza et al., 2019). Moreover, the values used for the analysis of rainfall effects were long-term annual means, thereby ignoring the fact that biocrusts show short-term responses to intensity and frequency of rainfall in individual years. This is illustrated by the very steep increase in biomass following a year of above-average rainfall (Figure 4).

In contrast to rainfall, leaf litter is a factor that clearly negatively affected the establishment and growth of total biocrust and cyanobacteria biocrusts in the Caatinga, thus confirming earlier studies (e.g., Boeken and Orenstein, 2001). However, litter did not influence biocrust cover between old growth and regeneration forests, despite differences in standing biomass among stages of forest regeneration (Souza et al., 2019). This may be partly accounted by abundance and density of woody parts of the vegetation, but also be caused by the fact that leaf biomass is known to rapidly reach a plateau as forest stands mature (Tadaki, 1977). To our knowledge, the reported estimate of biocrust cover 
in the Catimbau National Park (ca. 8\% of the total area), represent the first quantitative assessment for tropical dry forests. Studies in savannas in southern Africa, one of the few investigations done in woodland ecosystems, found biocrust cover reaching $<1 \%$ (except for one site in Sonop province with up to $20 \%$; Jürgens et al., 2010). It should be emphasized that the Caatinga human-modified landscapes provide suitable conditions for the development of biocrust assemblages that have been traditionally considered "typical" of relatively undisturbed arid habitats (Belnap, 2001b). In the Caatinga, the best environment for biocrust development, considering physiological performance, successional development, ground cover and persistence, consists of habitats free of vascular plants and lack of soil disturbance. But vascular plants can also have a beneficial effect on biocrust presence: Caatinga human-modified landscapes usually support high stock rates; i.e., 4-6 goats per $\mathrm{km}^{2}$, particularly across regenerating forest stands and old fields (11 goats per $\mathrm{km}^{2}$; Melo, 2017). Although goats consume litter, intense trampling does not allow biocrusts to settle and develop toward late successional stages, as confirmed by consistent negative relationships between goat trails and biocrusts in this study and previously published studies (Guo et al., 2008; Bowker et al., 2013; Ferrenberg et al., 2017). Goat-induced disturbance, which leads to a lower abundance of biocrust presence, except underneath shrubs, is therefore a plausible mechanism behind the unsuspected positive association observed between biocrusts and smallstatured shrubs, when plant presence usually would reduce biocrust distribution. Although more subject to deposition of litter and competition for light, biocrusts beneath small shrubs likely benefit from reduced trampling, particularly beneath less palatable shrubs, such as latex-bearing Jatropha and Croton species, and reduced evaporation through shading (Bowker et al., 2005; Zhang et al., 2016), especially at sites with high disturbance (Tabeni et al., 2014).

\section{Biocrusts as Ecosystem Service Providers and Their Role for Dry-Forest Resilience}

Biocrusts have been reported to influence several ecosystem-level processes, some of which can be considered as ecological services of local and global relevance. Understanding of biogeochemical cycles, including carbon cycling of biocrusts, is limited in the Caatinga (Elbert et al., 2012; Moura et al., 2016; Althoff et al., 2018). Cyanobacteria-dominated biocrusts double the soil organic carbon (SOC) content in the first $\mathrm{cm}$ of soil when compared to open soil, at both sites. The higher disturbance at the early site reduced the natural SOC stock in the soil and in the biocrust by half in comparison to the undisturbed site. However, the loss of SOC in bare soil can be neutralized by the presence of biocrusts which nonetheless double the SOC amount in underlying soil. A higher SOC content in the late biocrust is most likely attributed to a different species composition with later successional cyanobacteria (e.g., Nostoc sp.) being able to sequester more carbon (Lange, 2001). Interestingly, no difference of SOC content could be detected between either the wet or the dry year, even though one of the dominant organisms in both crusts, Microcoleus vaginatus, is highly adapted to rain pulses and should increase the SOC content of the soil during a very rainy season (Ferrenberg et al., 2015; Tucker et al., 2019). This lack of feedback could be explained by the fact that during years with little or no rainfall, both biocrust growth and decomposition is restricted (e.g., Thomas et al., 2011), and net loss in SOC is probably low. Additionally, SOC input might not only be due to increased net primary productivity of the biocrust itself but caused by the dust-trapping mechanism of the rough surface of biocrusts (Belnap, 2003). This is not influenced by the precipitation amount and collects nutrient rich dust, eroded at other sites. This theory is supported by measuring biomass, using chlorophyll $a$ as a proxy for net primary productivity, which showed a pronounced increase in biocrust biomass at both sites after the wet year without an increase of SOC. Disturbance had a negative impact on biocrust growth as biomass increase was only one third of that in the undisturbed habitat. The SOC stocks of topsoils with or without biocrusts fit well within the range of reported values for the Caatinga, related to other habitats it is very low (Table 3). Values resulting from this study might underestimate the actual SOC input by biocrusts in the Caatinga. Later successional stages including bryophytes and lichens, which have been excluded in this analysis, have higher carbon sequestration values (Lange, 2001) and react different to moisture and temperature changes than cyanobacterial dominated crusts (Tucker et al., 2019). The carbon stored in biocrusts represents ca. $7 \%$ of the carbon sequestered in aboveground biomass, estimated in a recent quantification of standing biomass in the Caatinga (Souza et al., 2019). The loss of such a considerable fraction of the overall carbon balance due to climate change or increasing disturbance might seriously threaten this fragile ecosystem and reduce its resilience to mitigate human impacts. While our results suggest a considerable influence of biocrusts on the Caatinga ecosystem, one should be mindful that they reflect carbon sequestration and biocrust growth of two sites at opposite ends of the disturbance gradient. In view of the complexity and patchiness of the human-modified Caatinga (Silva et al., 2017), a future research agenda should therefore aim at exploring additional environmental conditions and stages of forest regeneration. Nevertheless, the control soils of both study sites were equal in SOC and chlorophyll content, indicating that the observed differences were in fact based on biocrust presence and biocrust age. These in turn are shaped by the disturbance regime found at the sites. Filamentous cyanobacteria such as those from the dominating genera in our focal landscapes (i.e., Scytonema sp. and Microcoleus vaginatus) have been indicated as aggregators of sandy soils (Ferrenberg et al., 2015) thus reducing soil runoff and degradation (i.e., a key service in crop/pasturelands Pimentel et al., 1987). At landscape and regional scale, the Caatinga can be approached as a successional mosaic through which local farmers support livelihood by forest products and services such as recovery of nutrient stocks via forest regeneration. Unfortunately, the Caatinga dry forest has been driven toward desertification over large areas as soils become deeply depauperated due to superficial erosion (i.e., runoff) and nutrient exportation via crops/livestock (Leal et al., 2005; Vieira et al., 2015). Local depletion of forest regeneration sources, such as seeds, seedlings and resprouts can 
TABLE 3 | Overview of published and own (highlighted in gray) data on soil organic carbon (SOC) stocks in the Caatinga and other semi-arid ecosystems.

\begin{tabular}{|c|c|c|c|}
\hline Area/Organism & SOC $\mathbf{g ~ k g}^{-1}$ & Depth & Publication \\
\hline Early Site cyanobacterial biocrust & $10.67 \pm 4.50$ & $1 \mathrm{~cm}$ & This study \\
\hline Early Site soil & $6.04 \pm 2.30$ & $1 \mathrm{~cm}$ & This study \\
\hline Late Site cyanobacterial biocrust & $19.82 \pm 4.04$ & $1 \mathrm{~cm}$ & This study \\
\hline Late Site soil & $8.70 \pm 4.54$ & $1 \mathrm{~cm}$ & This study \\
\hline Caatinga slash and burn recovering soil & 8.61 & $20 \mathrm{~cm}$ & Freitas et al., 2012 \\
\hline Caatinga preserved soil & 11.62 & $20 \mathrm{~cm}$ & Freitas et al., 2012 \\
\hline Horqin Desert moss biocrust & $6.53 \pm 4.63$ & $10 \mathrm{~cm}$ & Li et al., 2017 \\
\hline Western Loess Plateau moss biocrust & $5.07 \pm 0.16$ & $10 \mathrm{~cm}$ & Li et al., 2017 \\
\hline Mu Us Desert Cyanobacterial and moss biocrust & $10.59 \pm 4.93$ & $10 \mathrm{~cm}$ & Li et al., 2017 \\
\hline Tengger-Alxa Desert mixed lichen, moss, cyanobacterial biocrust & $4.86 \pm 0.77$ & $10 \mathrm{~cm}$ & Li et al., 2017 \\
\hline Guerbantunggut Desert cyanobacterial and lichen biocrust & $2.38 \pm 0.62$ & $10 \mathrm{~cm}$ & Li et al., 2017 \\
\hline Qaidam Desert cyanobacterial biocrust & $0.41 \pm 0.17$ & $10 \mathrm{~cm}$ & Li et al., 2017 \\
\hline Guerbantunggut desert, moss biocrust (Bryum argenteum) & $\sim 2.2-5$ & $5 \mathrm{~cm}$ & Zhao et al., 2018 \\
\hline Area/Organism & SOC Mg ha ${ }^{-1}$ & Depth & Publication \\
\hline Early site cyanobacterial biocrust & $1.40 \pm 0.60$ & $1 \mathrm{~cm}$ & This study \\
\hline Early Site soil & $0.77 \pm 0.30$ & $1 \mathrm{~cm}$ & This study \\
\hline Late Site cyanobacterial biocrust & $2.49 \pm 0.54$ & $1 \mathrm{~cm}$ & This study \\
\hline Late Site soil & $1.13 \pm 0.60$ & $1 \mathrm{~cm}$ & This study \\
\hline Caatinga soil & 20.00 & $10 \mathrm{~cm}$ & Tiessen et al., 1998 \\
\hline Caatinga soil & 26.20 & $10 \mathrm{~cm}$ & Kauffman et al., 1993 \\
\hline Caatinga soil & 4.14 & $5 \mathrm{~cm}$ & Schulz et al., 2016 \\
\hline Caatinga soil & 17.00 & $5-60 \mathrm{~cm}$ & Schulz et al., 2016 \\
\hline Caatinga soil & $35.13-46.46$ & $40 \mathrm{~cm}$ & Barros et al., 2015 \\
\hline Caatinga slash and burn recovering soil & 23.15 & $20 \mathrm{~cm}$ & Althoff et al., 2018 \\
\hline Caatinga preserved soil & 31.85 & $20 \mathrm{~cm}$ & Althoff et al., 2018 \\
\hline Deserts and Semi Deserts soil & 57.00 & Across all horizons & Prentice et al., 2001 \\
\hline Tropical Savannas and Grasslands soil & 90.00 & Across all horizons & Prentice et al., 2001 \\
\hline Tropical Forest soil & 122.00 & Across all horizons & Prentice et al., 2001 \\
\hline Temperate Forest soil & 147.00 & Across all horizons & Prentice et al., 2001 \\
\hline Boreal Forest soil & 274.00 & Across all horizons & Prentice et al., 2001 \\
\hline
\end{tabular}

also be important (Tabarelli et al., 2017). Increased aridity (as predicted by climate change models; Torres et al., 2017) can magnify this human-induced degradation. In this scenario, it is reasonable to propose an unlimited number of connections between biocrusts, soil attributes/amelioration, forest recovery and human well-being/sustainability. As a working hypothesis, soil engineering by biocrusts, for example, enhances crop production, retard soil degradation on crops fields, favor forest recovery after land abandonment and old-growth forest productivity (i.e., higher forest resilience). Facilitation/nucleation promoted by sparse shrub-biocrust association may represent the best opportunity for forest regeneration across degraded habitats covering naturally poor soils, such as those in our focal landscape. In other words, biocrusts are connected to ecosystem resistance/resilience.

In summary, biocrusts seem to be a conspicuous and highly diverse component of Caatinga human-modified landscapes, extending the ecological role played by these associations to a prior overlooked ecosystem type. Furthermore, biocrusts benefit from the establishment of second-growth forests, in which they proliferate, reaching considerable coverage, although they are exposed to the controlling effects imposed by goats, litter cover and soil attributes. Such a positive synergism between human populations and biocrusts may result in a more crucial ecological role played by biocrusts as humans proceed with the encroachment of tropical landscapes, including those covered by forest vegetation. Although the presence of woody vegetation may impose some negative impacts on biocrusts (i.e., competition and litter cover) it also appears to provide protection against intense goat trampling. In this perspective, there must be an optimum combination for biocrusts considering vascular plant cover and goat pressure. Biocrusts act as carbon sequestering fertilizers of the Caatinga soils and their cover benefits from human presence. However, anthropogenic disturbance will lead to a considerable decrease in this ecosystem service provided by biocrusts, even if their coverage is not affected. Considering the intense dynamics of land use provoked by shifting cultivation and livestock breeding in the Caatinga, future studies need to investigate functions and services provided by biocrusts, particularly as drivers for forest regeneration and 
as a prevention of further desertification, as they are crucial for sustainable use of the Caatinga.

\section{DATA AVAILABILITY STATEMENT}

The raw data supporting the conclusions of this manuscript will be made available by the authors, without undue reservation, to any qualified researcher.

\section{AUTHOR CONTRIBUTIONS}

RW, MT, IL, BB, MS, and AM conceived and planned the experiment. AM, MS, and FO carried out the experiments with help from BB. MS and AM analyzed the data. BB, RW, and MT contributed to the interpretation of the results. MS took the lead in writing the manuscript. MT, RW, BB, and IL supervised the project. All authors provided critical feedback and helped shape the research, analysis and manuscript.

\section{FUNDING}

This study was funded by the Coordenação de Aperfeiçoamento de Pessoal de Nível Superior (CAPES project ID: $88881.030482 / 2013-01)$ and the Conselho Nacional de

\section{REFERENCES}

Althoff, T. D., Menezes, R. S. C., de Siqueira Pinto, A., Pareyn, F. G. C., de Carvalho, A. L., Martins, J. C. R., et al. (2018). Adaptation of the century model to simulate $\mathrm{C}$ and $\mathrm{N}$ dynamics of Caatinga dry forest before and after deforestation. Agric. Ecosyst. Environ. 254, 26-34. doi: 10.1016/j.agee.2017.11.016

Arnan, X., Leal, I. R., Tabarelli, M., Andrade, J. F., Barros, M. F., Câmara, T., et al. (2018). A framework for deriving measures of chronic anthropogenic disturbance: surrogate, direct, single and multi-metric indices in Brazilian Caatinga. Ecol. Indic. 94, 274-282. doi: 10.1016/j.ecolind.2018.07.001

Arnon, D. I. (1949). Copper enzymes in isolated chloroplasts. Polyphenoloxidase in Beta vulgaris. Plant Physiol. 24, 1-15. doi: 10.1104/pp.24.1.1

Ayuso, S. V., Silva, A. G., Nelson, C., Barger, N. N., and Garcia-Pichel, F. (2017). Microbial nursery production of high-quality biological soil crust biomass for restoration of degraded dryland soils. Appl. Environ. Microbiol. 83, e02179e02116. doi: 10.1128/AEM.02179-16

Barger, N. N., Weber, B., Garcia-Pichel, F., Zaady, E., and Belnap, J. (2016). "Patterns and controls on nitrogen cycling of biological soil crusts," in Biological Soil Crusts: An Organizing Principle in Drylands, eds B. Weber, B. Büdel, and J. Belnap (Cham: Springer), 257-285.

Barros, J. D. S., Chaves, L. G., and Pereira, W. E. (2015). Carbon and nitrogen stocks under different management systems in the Paraiban Serto. Afr. J. Agric. Res. 10, 130-136. doi: 10.5897/AJAR2014.8706

Belnap, J. (1995). Surface disturbances: their role in accelerating desertification. Environ. Monit. Assess. 37, 39-57. doi: 10.1007/BF00546879

Belnap, J. (2001a). "Comparative structure of physical and biological soil crusts," in Biological Soil Crusts: Structure, Function, and Management, eds J. Belnap, O. L. Lange (Berlin; Heidelberg: Springer), 177-91.

Belnap, J. (2001b). "Factors influencing nitrogen fixation and nitrogen release in biological soil crusts," in Biological Soil Crusts: Structure, Function, And Management, eds J. Belnap and O. L. Lange (Berlin; Heidelberg: Springer), 241-261.

Belnap, J. (2003). The world at your feet: desert biological soil crusts. Front. Ecol. Environ. 1, 181-189. doi: 10.1890/1540-9295(2003)001<0181:TWAYFD>2.0.CO;2
Desenvolvimento Científico e Tecnológico (CNPq-PELD project ID: 403770/2012-2). The preparation of the manuscript was supported by the German-Brazilian PROBRAL program (CAPES process 88881.030482/2013-01; DAAD project ID: 57413496) to RW, IL, and MT.

\section{ACKNOWLEDGMENTS}

IL and MT acknowledge CNPq for productivity grants and MT also acknowledges the Alexander von Humboldt Foundation (Germany) for a research grant. Finally, the authors would like to thank Einar Timdal for the help of identifying the Bybbia cf. albomarginata lichen species and Kátia Pôrto and Bruno Silva for the identification of the bryophyte species. The authors would also like to thank Davi Jamelli for providing and creating the vegetation classes of the map in Figure 2, and Jens Brauneck for providing the overview picture of the Caatinga in Figure 1.

\section{SUPPLEMENTARY MATERIAL}

The Supplementary Material for this article can be found online at: https://www.frontiersin.org/articles/10.3389/fevo. 2019.00482/full\#supplementary-material

Belnap, J. (2006). The potential roles of biological soil crusts in dryland hydrologic cycles. Hydrol. Process. 20, 3159-3178. doi: 10.1002/hyp.6325

Belnap, J., and Büdel, B. (2016). "Biological soil crusts as soil stabilizers," in Biological Soil Crusts: An Organizing Principle In Drylands, eds B. Weber, B. Büdel, and J. Belnap (Cham: Springer), 305-320.

Belnap, J., Büdel, B., and Lange, O. L. (2001). "Biological soil crusts: characteristics and distribution," in Biological Soil Crusts: Structure, Function, and Management, eds J. Belnap and O. L. Lange (Berlin; Heidelberg: Springer), 3-30.

Belnap, J., and Gillette, D. A. (1998). Vulnerability of desert biological soil crusts to wind erosion: the influences of crust development, soil texture, and disturbance. J. Arid Environ. 39, 133-142. doi: 10.1006/jare.1998.0388

Belnap, J., and Lange, O. L. (Eds.). (2013). Biological Soil Crusts: Structure, Function, and Management, Vol. 150. Springer: Science \& Business Media

Belnap, J., Phillips, S. L., Herrick, J. E., and Johansen, J. R. (2007). Wind erodibility of soils at Fort Irwin, California (Mojave Desert), USA, before and after trampling disturbance: implications for land management. Earth Surface Process. Landforms 32, 75-84. doi: 10.1002/esp.1372

Belnap, J., Phillips, S. L., and Troxler, T. (2006). Soil lichen and moss cover and species richness can be highly dynamic: the effects of invasion by the annual exotic grass Bromus tectorum, precipitation, and temperature on biological soil crusts in SE Utah. Appl. Soil Ecol. 32, 63-76. doi: 10.1016/j.apsoil.2004.12.010

Belnap, J., Weber, B., and Büdel, B. (eds). (2016). "Biological soil crusts as an organizing principle in drylands," in Biological Soil Crusts: An Organizing Principle in Drylands (Cham: Springer), 3-13.

Berkeley, A., Thomas, A. D., and Dougill, A. J. (2005). Cyanobacterial soil crusts and woody shrub canopies in Kalahari rangelands. Afr. J. Ecol. 43, 137-145. doi: 10.1111/j.1365-2028.2005.00560.x

Bischoff, H. C. (1963). Some Soil Algae from Enchanted Rock and Related Algal Species. Austin, TX: University of Texas.

Black, C. A. (1965). Methods of Soil Analysis Part1 and 2. Madison, WI: American Society of Agronomy, Inc.

Boeken, B., and Orenstein, D. (2001). The effect of plant litter on ecosystem properties in a Mediterranean semi-arid shrubland. J. Veg. Sci. 12, 825-832. doi: $10.2307 / 3236870$ 
Bowker, M. A., Belnap, J., Büdel, B., Sannier, C., Pietrasiak, N., Eldridge, D. J., et al. (2016). "Controls on distribution patterns of biological soil crusts at micro-to global scales," in Biological Soil Crusts: An Organizing Principle In Drylands, eds B. Weber, B. Büdel, and J. Belnap (Cham: Springer), 173-197.

Bowker, M. A., Belnap, J., Davidson, D. W., and Goldstein, H. (2006). Correlates of biological soil crust abundance across a continuum of spatial scales: support for a hierarchical conceptual model. J. Appl. Ecol. 43, 152-163. doi: 10.1111/j.1365-2664.2006.01122.x

Bowker, M. A., Belnap, J., Davidson, D. W., and Phillips, S. L. (2005). Evidence for micronutrient limitation of biological soil crusts: importance to arid-lands restoration. Ecol. Appl. 15, 1941-1951. doi: 10.1890/04-1959

Bowker, M. A., Eldridge, D. J., Val, J., and Soliveres, S. (2013). Hydrology in a patterned landscape is co-engineered by soil-disturbing animals and biological crusts. Soil. Biol. Biochem. 61, 14-22. doi: 10.1016/j.soilbio.2013. 02.002

Briggs, A., and Morgan, J. W. (2008). Morphological diversity and abundance of biological soil crusts differ in relation to landscape setting and vegetation type. Aust. J. Bot. 56, 246-253. doi: 10.1071/BT07194

$\mathrm{Bu}, \mathrm{C}$., Wu, S., Han, F., Yang, Y., and Meng, J. (2015). The combined effects of moss-dominated biocrusts and vegetation on erosion and soil moisture and implications for disturbance on the Loess Plateau, China. PLoS ONE 10:e0127394. doi: 10.1371/journal.pone.0127394

Büdel, B., Darienko, T., Deutschewitz, K., Dojani, S., Friedl, T., Mohr, K. I., et al. (2009). Southern African biological soil crusts are ubiquitous and highly diverse in drylands, being restricted by rainfall frequency. Microb. Ecol. 57, 229-247. doi: 10.1007/s00248-008-9449-9

Büdel, B., Dulić, T., Darienko, T., Rybalka, N., and Friedl, T. (2016). "Cyanobacteria and algae of biological soil crusts," in Biological Soil Crusts: An Organizing Principle in Drylands, eds B. Weber, B. Büdel, and J. Belnap (Cham: Springer), 55-80.

Campbell, S. E. (1979). Soil stabilization by a prokaryotic desert crust: implications for precambrian land biota. Origins Life 9, 335-348. doi: 10.1007/BF009 26826

Castillo-Monroy, A. P., Maestre, F. T., Rey, A., Soliveres, S., and GarcíaPalacios, P. (2011). Biological soil crust microsites are the main contributor to soil respiration in a semiarid ecosystem. Ecosystems 14, 835-847. doi: 10.1007/s10021-011-9449-3

Chamizo, S., Belnap, J., Eldridge, D. J., Cantón, Y., and Issa, O. M. (2016). "The role of biocrusts in arid land hydrology," in Biological Soil Crusts: An Organizing Principle in Drylands, eds B. Weber, B. Büdel, and J. Belnap (Springer: Cham), 321-346.

Chamizo, S., Cantón, Y., Lázaro, R., and Domingo, F. (2013). The role of biological soil crusts in soil moisture dynamics in two semiarid ecosystems with contrasting soil textures. J. Hydrol. 489, 74-84. doi: 10.1016/j.jhydrol.2013.02.051

Concostrina-Zubiri, L., Huber-Sannwald, E., Martínez, I., Flores, J. F., ReyesAgüero, J. A., Escudero, A., et al. (2014). Biological soil crusts across disturbance-recovery scenarios: effect of grazing regime on community dynamics. Ecol. Appl. 24, 1863-1877. doi: 10.1890/13-1416.1

Condon, L. A., and Pyke, D. A. (2018). Resiliency of biological soil crusts and vascular plants varies among morphogroups with disturbance intensity. Plant Soil 433, 271-287. doi: 10.1007/s11104-018-3838-8

Deines, L., Rosentreter, R., Eldridge, D. J., and Serpe, M. D. (2007). Germination and seedling establishment of two annual grasses on lichen-dominated biological soil crusts. Plant Soil 295, 23-35. doi: 10.1007/s11104-007-9256-y

Duane Allen, C. (2010). Biogeomorphology and biological soil crusts: a symbiotic research relationship. Géomorphologie Relief Processus Environ. 16, 347-358. doi: $10.4000 /$ geomorphologie. 8071

Eamus, D. (1999). Ecophysiological traits of deciduous and evergreen woody species in the seasonally dry tropics. Trends Ecol. Evol. 14, 11-16. doi: 10.1016/S0169-5347(98)01532-8

Elbert, W., Weber, B., Burrows, S., Steinkamp, J., Büdel, B., Andreae, M. O. et al. (2012). Contribution of cryptogamic covers to the global cycles of carbon and nitrogen. Nat. Geosci. 5:459. doi: 10.1038/ngeo1486

Eldridge, D. J., Bowker, M. A., Maestre, F. T., Alonso, P., Mau, R. L., Papadopoulos, J., et al. (2010). Interactive effects of three ecosystem engineers on infiltration in a semi-arid Mediterranean grassland. Ecosystems 13, 495-510. doi: $10.1007 /$ s10021-010-9335-4
Eldridge, D. J., and Rosentreter, R. (1999). Morphological groups: a framework for monitoring microphytic crusts in arid landscapes. J. Arid Environ. 41, 11-25. doi: 10.1006/jare.1998.0468

Eldridge, D. J., and Tozer, M. E. (1996). Distribution and floristics of bryophytes in soil crusts in semi-arid and arid eastern Australia. Aust. J. Bot. 44, 223-247. doi: 10.1071/BT9960223

Ettl, H., and Gärtner, G. (1996). Syllabus der Boden-, Luft-und Flechtenalge. New York, NY: Gustav Fischer Verlag.

Ferrenberg, S., Reed, S. C., and Belnap, J. (2015). Climate change and physical disturbance cause similar community shifts in biological soil crusts. Proc. Natl. Acad. Sci. 112, 12116-12121. doi: 10.1073/pnas.1509150112

Ferrenberg, S., Tucker, C. L., and Reed, S. C. (2017). Biological soil crusts: diminutive communities of potential global importance. Front. Ecol. Environ. 15, 160-167. doi: 10.1002/fee.1469

Freitas, A. D. S., de Sampaio, E. V. S. B., da Silva, B. L. R., de Almeida Cortez, J. S., and Menezes, R. S. C. (2012). How much nitrogen is fixed by biological symbiosis in tropical dry forests? 2. Herbs. Nutr. Cycling Agroecosystems 94, 181-192. doi: 10.1007/s10705-012-9545-6

Guo, Y., Zhao, H., Zuo, X., Drake, S., and Zhao, X. (2008). Biological soil crust development and its topsoil properties in the process of dune stabilization, Inner Mongolia, China. Environ. Geol. 54, 653-662. doi: 10.1007/s00254-007-1130-y

Harper, K. T., and Belnap, J. (2001). The influence of biological soil crusts on mineral uptake by associated vascular plants. J. Arid. Environ. 47, 347-357. doi: 10.1006/jare.2000.0713

Johnson, S. L., Kuske, C. R., Carney, T. D., Housman, D. C., Gallegos-Graves, L. V., and Belnap, J. (2012). Increased temperature and altered summer precipitation have differential effects on biological soil crusts in a dryland ecosystem. Glob. Chang. Biol. 18, 2583-2593. doi: 10.1111/j.1365-2486.2012.02709.x

Jung, P., Briegel-Williams, L., Schermer, M., and Büdel, B. (2018). Strong in combination: polyphasic approach enhances arguments for cold-assigned cyanobacterial endemism. MicrobiologyOpen 8:e00729. doi: 10.1002/ mbo3.729

Jürgens, N., Haarmeyer, D. H., Luther-Mosebach, J., Dengler, J., Finckh, M., and Schmiedel, U. (2010). Biodiversity in southern Africa. Vol 1: Patterns at local scale-the BIOTA Observatories. Göttingen; Windhoek: Klaus Hess Publishers.

Kauffman, J. B., Sanford, R. L. Jr., Cummings, D. L., Salcedo, I. H., and Sampaio, E. V. S. B. (1993). Biomass and nutrient dynamics associated with slash fires in neotropical dry forests. Ecology 74, 140-151. doi: 10.2307/1939509

Kidron, G. J., Herrnstadt, I., and Barzilay, E. (2002). The role of dew as a moisture source for sand microbiotic crusts in the Negev Desert, Israel. J. Arid Environ. 52, 517-533. doi: 10.1006/jare.2002.1014

Kleiner, E. F., and Harper, K. T. (1972). Environment and community organization in grasslands of Canyonlands National Park. Ecology 53, 299-309. doi: $10.2307 / 1934086$

Komárek, J., and Anagnostidis, K. (1998). "Cyanoprokaryota, 1. Teil Chroococcales," in Süßwasserflora von Mitteleuropa 19/1, eds H. Ettl, G. Gärtner, H. Heynig, and D. Mollenhauer (Jena: Gustav Fischer Verlag), 548.

Komárek, J., and Anagnostidis, K. (2005). "Cyanoprokaryota, 2. Teil oscillatoriales," in Süßwasserflora von Mitteleuropa 19/2 Elsevier GmbH, eds B. Büdel, G. Gärtner, L. Krienitz, and M. Schagerl (München), 759.

Lange, O. L. (2001). "Photosynthesis of soil-crust biota as dependent on environmental factors," in Biological Soil Crusts: Structure, Function, and Management (Berlin; Heidelberg: Springer), 217-240.

Leal, I. R., Silva, J. M. C., Tabarelli, M., and Lacher, T. E. Jr. (2005). Changing the course of biodiversity conservation in the caatinga of northeastern Brazil. Conserv. Biol. 19, 701-706. doi: 10.1111/j.1523-1739.2005.00703.x

Levy, E. B., and Madden, E. (1933). The point method for pasture analysis. Nova Zelândia J. Agr. V. 46, 267-279.

Li, X. R., Song, G., Hui, R., and Wang, Z. R. (2017). Precipitation and topsoil attributes determine the species diversity and distribution patterns of crustal communities in desert ecosystems. Plant Soil 420, 163-175. doi: 10.1007/s11104-017-3385-8

Maestre, F. T., and Cortina, J. (2002). Spatial patterns of surface soil properties and vegetation in a Mediterranean semi-arid steppe. Plant Soil 241, 279-291. doi: 10.1023/A:1016172308462

Maestre, F. T., Escolar, C., Ladron de Guevara, M., Quero, J. S., Lázaro, R., DelgadoBaquerizo, M. et al. (2013). Changes in biocrust cover drive carbon cycle 
responses to climate change in drylands. Glob. Change Biol. 19, 3835-3847. doi: $10.1111 /$ gcb.12306

Mallen-Cooper, M., Eldridge, D. J., and Delgado-Baquerizo, M. (2018). Livestock grazing and aridity reduce the functional diversity of biocrusts. Plant Soil 429, 1-11. doi: 10.1007/s11104-017-3388-5

Marschall, M., and Proctor, M. C. (2004). Are bryophytes shade plants? Photosynthetic light responses and proportions of chlorophyll a, chlorophyll b and total carotenoids. Ann. Bot. 94, 593-603. doi: 10.1093/aob/ mch178

Maya, Y., and López-Cortés, A. (2002). Cyanobacterial microbiotic crusts in eroded soils of a tropical dry forest in the Baja California Peninsula, Mexico. Geomicrobiol. J. 19, 505-518. doi: 10.1080/014904502900 98469

McCune, B., and Rosentreter, R. (1995). Field Key to Soil Lichens of Central and Eastern Oregon. Unpublished Report, Oregon State University and USDI BLM.

Melo, F. P. (2017). "The socio-ecology of the Caatinga: understanding how natural resource use shapes an ecosystem," in Caatinga, eds J. M. C. Silva, I. R. Leal, and M. Tabarelli (Cham: Springer), 369-382.

Moura, P. M., Althoff, T. D., Oliveira, R. A., Souto, J. S., Souto, P. C., Menezes, R. S., et al. (2016). Carbon and nutrient fluxes through litterfall at four succession stages of Caatinga dry forest in Northeastern Brazil. Nutr. Cycl. Agroecosyst. 105, 25-38. doi: 10.1007/s10705-016-9771-4

Oliveira, D. G., Prata, A. P. D. N., Souto, L. S., and Ferreira, R. A. (2013). Does the edge effect influence plant community structure in a tropical dry forest? Revista Árvore 37, 311-320. doi: 10.1590/S0100-67622013000200012

Passos, L., and Oliveira, P. S. (2004). Interaction between ants and fruits of Guapira opposita (Nyctaginaceae) in a Brazilian sandy plain rainforest: ant effects on seeds and seedlings. Oecologia 139, 376-382. doi: 10.1007/s00442-0041531-5

Pennington, R. T., Lavin, M., and Oliveira-Filho, A. (2009). Woody plant diversity, evolution, and ecology in the tropics: perspectives from seasonally dry tropical forests. Annu. Rev. Ecol. Evol. Syst. 40, 437-457. doi: 10.1146/annurev.ecolsys.110308.120327

Pimentel, D., Allen, J., Beers, A., Guinand, L., Linder, R., McLaughlin, P., et al. (1987). World agriculture and soil erosion. BioScience 37, 277-283. doi: $10.2307 / 1310591$

Prentice, I. C., Farquhar, G. D., Fasham, M. J. R., Goulden, M. L., Heimann, M., Jaramillo, V. J., et al. (2001). "The carbon cycle and atmospheric carbon dioxide," in Climate Change 2001: The Scientific Basis. Contributions of Working Group I to the Third Assessment Report of the Intergovernmental Panel on Climate Change, eds J. T. Houghton, Y. Ding, D. J. Griggs, M. Noguer, P. J. van der Linden, X. Dai, et al. (Cambridge, UK: Cambridge University Press), 185-237.

Rito, K. F., Arroyo-Rodríguez, V., Queiroz, R. T., Leal, I. R., and Tabarelli, M. (2017). Precipitation mediates the effect of human disturbance on the Brazilian Caatinga vegetation. J. Ecol. 105, 828-838. doi: 10.1111/1365-2745.12712

Rodriguez-Caballero, E., Belnap, J., Büdel, B., Crutzen, P. J., Andreae, M. O., Pöschl, U., et al. (2018). Dryland photoautotrophic soil surface communities endangered by global change. Nat. Geosci. 11:185. doi: 10.1038/s41561-018-0072-1

Ronen, R., and Galun, M. (1984). Pigment extraction from lichens with dimethyl sulfoxide (DMSO) and estimation of chlorophyll degradation. Environ. Exp. Bot. 24, 239-245. doi: 10.1016/0098-8472(84)90004-2

Rosentreter, R., and Belnap, J. (2001). "Biological soil crusts of North America," in Biological Soil Crusts: Structure, Function, And Management, eds J. Belnap, O. L. Lange (Berlin; Heidelberg: Springer), 31-50

Sampaio, E. V. S. B. (1995). "Overview of the brazilian caatinga," in Seasonally Dry Tropical Forests, eds S. H. Bullock, H. A. Mooney, and E. Medina (Cambridge: University Press), 35-63.

Sancho, L. G., Belnap, J., Colesie, C., Raggio, J., and Weber, B. (2016). "Carbon budgets of biological soil crusts at micro-, meso-, and global scales," in Biological Soil Crusts: An Organizing Principle In Drylands, eds B. Weber, B. Büdel, and J. Belnap (Cham: Springer), 287-304

Schulz, K., Voigt, K., Beusch, C., Almeida-Cortez, J. S., Kowarik, I., Walz, A., et al. (2016). Grazing deteriorates the soil carbon stocks of Caatinga forest ecosystems in Brazil. For. Ecol. Manage. 367, 62-70. doi: 10.1016/j.foreco.2016.02.011
Seitz, S., Nebel, M., Goebes, P., Käppeler, K., Schmidt, K., Shi, X., et al. (2017). Bryophyte-dominated biological soil crusts mitigate soil erosion in an early successional Chinese subtropical forest. Biogeosciences 14, 5775-5788. doi: 10.5194/bg-14-5775-2017

Seppelt, R. D., Downing, A. J., Deane-Coe, K. K., Zhang, Y., and Zhang, J. (2016). "Bryophytes within biological soil crusts," in Biological Soil Crusts: An Organizing Principle in Drylands, eds B. Weber, B. Büdel, and J. Belnap (Cham: Springer), 101-120.

Silva, J. M. C., Barbosa, L. C. F., Leal, I. R., and Tabarelli, M. (2017). “The Caatinga: understanding the challenges," in Caatinga, eds J. M. C. Silva, I. R. Leal, and M. Tabarelli (Cham: Springer), 3-19.

SNE (2002). Projeto Técnico para a Criação do Parque Nacional do Catimbau/PE. Proposta para Criação do Parque Nacional do Catimbau/PE, Sociedade Nordestina de Ecologia.

Song, G., Li, X., and Hui, R. (2017). Effect of biological soil crusts on seed germination and growth of an exotic and two native plant species in an arid ecosystem. PLoS ONE 12:e0185839. doi: 10.1371/journal.pone.0185839

Souza, D. G., Sfair, J. C., de Paula, A. S., Barros, M. F., Rito, K. F., and Tabarelli, M. (2019). Multiple drivers of aboveground biomass in a humanmodified landscape of the Caatinga dry forest. For. Ecol. Manage. 435, 57-65. doi: 10.1016/j.foreco.2018.12.042

Szyja, M., Colesie, C., and Büdel, B. (2018). Ecophysiological characterization of early successional biological soil crusts in heavily human-impacted areas. Biogeosciences 15, 1919-1931. doi: 10.5194/bg-15-1919-2018

Tabarelli, M., Aguiar, A. V., Ribeiro, M. C., Metzger, J. P., and Peres, C. A. (2010). Prospects for biodiversity conservation in the Atlantic Forest: lessons from aging human-modified landscapes. Biol. Conserv. 143, 2328-2340. doi: 10.1016/j.biocon.2010.02.005

Tabarelli, M., Leal, I. R., Scarano, F. R., and da Silva, J. M. C. (2017). “The future of the Caatinga," in Caatinga, eds J. M. C. Silva, I. R. Leal, and M. Tabarelli (Cham: Springer), 461-474.

Tabeni, S., Garibotti, I. A., Pissolito, C., and Aranibar, J. N. (2014). Grazing effects on biological soil crusts and their interaction with shrubs and grasses in an arid rangeland. J. Vegetation Sci. 25, 1417-1425. doi: 10.1111/jvs.12204

Tadaki, Y. (1977). Studies on the production structure of forest. XVIII. Structure and primary production in subalpine "dead trees strips" Abies forest near Mt. Asahi. Jpn J. Ecol, 27, 83-90.

Thomas, A. D. (2012). Impact of grazing intensity on seasonal variations in soil organic carbon and soil CO2 efflux in two semiarid grasslands in southern Botswana. Philos. Trans. R. Soc. Lond. B. Biol. Sci. 367, 3076-3086. doi: 10.1098/rstb.2012.0102

Thomas, A. D., Hoon, S. R., and Dougill, A. J. (2011). Soil respiration at five sites along the Kalahari Transect: effects of temperature, precipitation pulses and biological soil crust cover. Geoderma 167, 284-294. doi: 10.1016/j.geoderma.2011.07.034

Thompson, W. A., Eldridge, D. J., and Bonser, S. P. (2006). Structure of biological soil crust communities in Callitris glaucophylla woodlands of New South Wales, Australia. J. Vegetation Sci. 17, 271-280. doi: 10.1111/j.1654-1103.2006.tb02446.x

Throop, H. L., Archer, S. R., Monger, H. C., and Waltman, S. (2012). When bulk density methods matter: implications for estimating soil organic carbon pools in rocky soils. J. Arid Environ. 77, 66-71. doi: 10.1016/j.jaridenv.2011. 08.020

Tiessen, H., Feller, C., Sampaio, E. V. S. B., and Garin, P. (1998). Carbon sequestration and turnover in semiarid savannas and dry forest. Clim. Change 40, 105-117. doi: 10.1023/A:1005342932178

Torres, R. R., Lapola, D. M., and Gamarra, N. L. R. (2017). Future climate change in the Caatinga. in Caatinga, eds J. M. C. Silva, I. R. Leal, and M. Tabarelli (Cham: Springer), 383-410

Tucker, C. L., Ferrenberg, S., and Reed, S. C. (2019). Climatic sensitivity of dryland soil CO 2 fluxes differs dramatically with biological soil crust successional state. Ecosystems 22, 15-32. doi: 10.1007/s10021-018-0250-4

Vieira, R. D. S. P., Tomasella, J., Alvalá, R. C. S., Sestini, M. F., Affonso, A. G., Rodriguez, D. A., et al. (2015). Identifying areas susceptible to desertification in the Brazilian northeast. Solid Earth 6, 347-360. doi: 10.5194/se-6-3472015

Weber, B., Bowker, M., Zhang, Y., and Belnap, J. (2016). "Natural recovery of biological soil crusts after disturbance," in Biological Soil Crusts: An 
organizing Principle in Drylands, eds B. Weber, B. Büdel, and J. Belnap (Cham: Springer), 479-498.

Zhang, Y., Aradottir, A. L., Serpe, M., and Boeken, B. (2016). "Interactions of biological soil crusts with vascular plants," in Biological Soil Crusts: An Organizing Principle In Drylands, eds B. Weber, B. Büdel, and J. Belnap (Cham: Springer), 385-406.

Zhao, R., Hui, R., Liu, L., Xie, M., and An, L. (2018). Effects of snowfall depth on soil physical-chemical properties and soil microbial biomass in mossdominated crusts in the Gurbantunggut Desert, Northern China. CATENA. 169, 175-182. doi: 10.1016/j.catena.2018.05.042
Conflict of Interest: The authors declare that the research was conducted in the absence of any commercial or financial relationships that could be construed as a potential conflict of interest.

Copyright (๑) 2019 Szyja, Menezes, Oliveira, Leal, Tabarelli, Büdel and Wirth. This is an open-access article distributed under the terms of the Creative Commons Attribution License (CC BY). The use, distribution or reproduction in other forums is permitted, provided the original author(s) and the copyright owner(s) are credited and that the original publication in this journal is cited, in accordance with accepted academic practice. No use, distribution or reproduction is permitted which does not comply with these terms. 